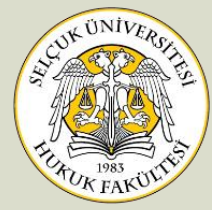

\title{
TERÖR SUÇLARIYLA MÜCADELEDE YENİ KONSEPT: ÖNALAN SUÇLARI - BGH KARARLARI IŞIĞINDA ALMANYA ÖRNEĞI
}

\author{
Dr. Öğr. Üyesi Fatih YURTLU*
}

Öz

Bir fiilin cezalandırılabilmesi için belirli bir nitelik ve niceliğe ulaşması gerekir. $\mathrm{Bu}$ bakımdan, bir suçun hazırlık hareketi evresi kural olarak ceza hukuku sorumluluğunu gerektirmez. Buna karşılık, bazı hazırlık hareketleri müstakil suçlar olarak düzenlenerek cezalandırılması amaçlanmaktadır. Suç işlemek amacıyla örgüt kurma, yönetme, üye olma, yardım etme fiilleri de esasında işlenmesi amaçlanan suçlar bakımından birer hazırlık hareketi niteliğindedir. Ancak korudukları hukuki değer göz önüne alınarak ilgili fiiller, hem Alman hem de Türk kanun koyucular tarafından müstakil birer suç olarak düzenlenmiştir. Böylece esasında hazırlık hareketi niteliğindeki söz konusu fiillerin cezalandırılması mümkün olmaktadır. Bu çalışmada, "önalan suçları" olarak ifade edilen ve özellikle terör (örgüt) suçları bakımından "hazırlık hareketi" oluşturan bazı fiillerin cezalandırılmasına yönelik devam eden eğilim, konuya ilişkin BGH kararları ışığında suç genel teorisi ve ceza hukuku temel ilkeleri bakımından incelenmiştir.

\section{Anahtar Kelimeler}

Önalan Suçları • Hazırlık Hareketi • Terör Suçları • Örgütlü Suçlar • Teşebbüs

Dr. Öğr. Üyesi, Alanya Alaaddin Keykubat Üniversitesi İktisadi ve İdari Bilimler Fakültesi, Antalya, Türkiye| Asst. Prof., Alanya Alaaddin Keykubat University, Faculty of Economics and Administrative Sciences, Department of International Trade, Antalya, Turkey.

凤fatihyurtlu@gmail.com • ORCiD 0000-0003-2905-7900

Atıf Şekli | Cite As: YURTLU, Fatih “Terör Suçlarıyla Mücadelede Yeni Konsept: Önalan Suçları-BGH Kararları Işı̆̆ında Almanya Örneği", SÜHFD., C. 29, S. 3, 2021, s. 2169-2208.

İntihal | Plagiarism: Bu makale intihal programında taranmış ve en az iki hakem incelemesinden geçmiştir. | This article has been scanned via a plagiarism software and reviewed by at least two referees. 


\section{NEUES KONZEPT IN DER BEKÄMPFUNG DES TERRORISMUS: VORFELDSDELIKTE - BEISPIELE AUS DEUTSCHLAND UNTER BERÜCKSICHTIGUNG EINIGER BGH -ENTSCHEIDUNGEN}

\section{Zusammenfassung}

Eine Tat ist dann strafbar, wenn sie eine bestimmte Qualifikation erlangt hat. In diesem Zusammenhang wird angenommen, dass die Vorbereitungshandlungen keiner Strafbarkeit bedürfen. Allerdings sind einige Vorbereitungshandlungen strafbar, wenn sie als eigenständige Straftaten gesetzlich vorgesehen sind. Gründung einer Vereinigung, deren Zweck in der Begehung von Straftaten liegt, das Mitgliedwerden in dieser sowie deren Unterstützung sind insofern Vorbereitungshandlungen als es um die Begehung von bezweckten Straftaten geht. Sowohl in Deutschland als auch in der Türkei sind sie jedoch mit der Begründung unter Strafdrohung gestellt, dass Schutz von einschlägigen Rechtsgüter dies erfordere. Dabei wird dem ansonsten angenommen Grundsatz, dass Vorbereitungshandlungen nicht strafbar sind, eine Ausnahme gemacht. Im vorliegenden Beitrag wird die Tendenz, weitere Vorbereitungshandlungen insbesondere im Bereich der Terrorismusbekämpfung als sog. Vorfeldsdelikte unter Strafe zu stellen, unter Berücksichtigung einiger BGH-Entscheidungen vor dem Hintergrund der Verbrechenslehre und der Strafgerechtigkeit untersucht.

\section{Stichwörter:}

Vorfeldsdelikte $\bullet$ Vorbereitungshandlung $\bullet$ Terrorismusdelikte $\bullet$ Vereinigungsdelikte $\bullet$ Versuchsstrafbarkeit

\section{GíRIŞ}

Örgütlü suçlar, tarihin eski dönemlerine uzanan bir suçluluk metodu olarak karşımıza çıkmasına rağmen "suç örgütleri" özellikle 20. yüzyılın başlarından itibaren uluslararası düzeyde fenomen haline gelmiş ve toplumları; siyasi, sosyal, ekonomik ve hukuki açıdan derinden etkilemeye başlamıştır. Bu etki, 20. yüzyılın başlarından ortasına kadar "çıkar amaçlı suç örgütleri"1 ekseninde yaşanırken, 20. yüzyılın ortasından

Suç örgütleri ve örgütlü suçluluk, kriminolojik anlamda çok farklı tasnife tabi tutulabilir. Bununla beraber, doktrinde en çok tercih edilen ve meri hukuki düzenlemelerine yansıyan temel yaklaşım, suç örgütlerinin "çıkar amaçlı suç örgütleri" ve "terör örgütleri" olarak ikiye ayrılmasıdır. NISCO, Attilio, "Organized Crime In Italian Criminal Law and Practice: An Overview of Some Current Problems", Dr. Silvia Tellenbach'a Armağan, Ankara 2018, s. 445. 
günümüze kadarki süreçte ise kendini daha çok "terör örgütleri" ekseninde hissettirmiştir. Önceleri, bulundukları coğrafyanın kendine has sosyo-kültürel yapısıyla özdeşleşen ve daha çok bölgesel faaliyet gösteren suç örgütü yapılanmaları, özellikle gelişen iletişim/ulaşım olanakları sayesinde öncelikle ulusal, akabinde uluslararası "organizasyonlar" halini almışlardır ${ }^{2}$.

Gelişen iletişim ve ulaşım olanaklarından azami ölçüde faydalanan suç örgütleri günümüzde, içinde bulundukları toplumların karşı karşıya kaldıkları siyasi/ekonomik krizleri de kullanarak önemli birer "gü̈c merkezi - figür" haline dönüşmüştür. Suç örgütleri; zamanla, yasa dişı yollardan müşterilerine mal ve hizmet sağlayan büyük firmalar halini almıştır". Özellikle "uyuşturucu madde imal ve ticareti, silah ve akaryakıt kaçakçılı̆̆ı, rüşvet, zimmet, irtikâp, ihaleye fesat karıştırma, fuhuş, yasadışı kumar ve bahis" gibi ekonomik çıkar amaçlı suçlar, günümüzde çok büyük oranda suç örgütlerinin faaliyetleri kapsamında işlenmektedir ${ }^{4}$. Hakeza, ekonomik çıkar amacıyla işlenen bu tip suçlardan elde edilen yüksek miktardaki maddi kazancın sanki meşru yollardan elde edilmiş gibi çeşitli vasıtalar kullanılarak meşru ekonomik sisteme dâhil edilmesi,

Kısaca "mafya" da denilen "çıkar amaçlı suçörgütleri" ile "terör örgütleri" arasındaki temel fark ise şudur: Terör örgütleri, hedefledikleri siyasal amaçlara ulaşmak için şiddet temelinde suç işlerken; mafya tipi suç örgütleri ise ekonomik çıkar elde etmek amacıyla suç işlemektedir. DÖNMEZER, Sulhi, "Organize Suçlulukla Mücadele", Galatasaray Üniversitesi Hukuk Fakültesi Dergisi, Kemal Oğuzman'a Armağan, Ocak 2002, sa. 1, y.1, s. 6.

Suç örgütlerinin kriminolojik yönden farklı görünüş biçimleri hakkında ayrıntılı bilgi için bkz. EVIKK, Vesile Sonay, Çıkar Amaçlı Örgütlenme Suçu, 1. Bası, İstanbul 2004, s. 36- 45. YURTLU, Fatih, Suç İşlemek Amaciyla Örgüt Kurma, Kurulmuş Örgütü Yönetme veya Bu Örgüte Üye Olma, Yayımlanmamış Yüksek Lisans Tezi, Gazi Üniversitesi Sosyal Bilimler Enstitüsü, Ankara 2013, s. 28 v.d.

2 Hatta daha da ileri gidilerek suç örgütlerinin günümüzdeki faaliyetlerini ifade etmek için "transnational" yani "sınıraşan" kavramı kullanılmaktadır. RAHMDEL, Mansour, "Organized Crimes and Organized Criminal Groups In the Iranian Criminal Law", Dr. Silvia Tellenbach'a Armağan, Ankara 2018, s. 583 - 584. NISCO, s. 445 446.

3 FIORENTINI, Gianluca / PELTZMAN, Sam, The Economics of Organised Crime, Cambridge University Press, 2005, s. 3. NISCO, s. 445.

4 ÖZGENÇ, İzzet, Suç Örgütleri, 13. Bası, Ankara 2020, s. 145. 
yani suçtan elde edilen malvarlığı değerlerinin aklanması da başka sosyolojik/ekonomik sorunlara neden olmaktadır ${ }^{5}$.

Günümüzde, suç örgütlerinin gerçekleştirdikleri yasa dişı faaliyetlerden elde ettikleri gelirlerin gelişmiş ülkelerin bütçeleri ile eşdeğer olduğu ifade edilmektedir' ${ }^{6}$. Bu denli büyük bir ekonomik güce hükmeden suç örgütleri, şiddeti de bir yöntem olarak kullanmak suretiyle meşru hukuki otoritelere baskı yapabilmektedir. Ekonomik çıkar amacıyla işlenen suçlardan elde edilen malvarlığı değerleri, küresel terör örgütlerinin birincil ilgi alanına girmektedir. Amaçladıkları siyasi hedefe ulaşmak için şiddeti bir yöntem olarak seçen terör örgütleri, çoğu zaman bu amaçlarına ulaşmak için ihtiyaçları olan mali kaynağı, işledikleri suçlardan temin etmektedir7. Dolayısıyla, suçtan elde edilen malvarlığı değerlerinin aklanması ile terörizmin finansmanı da çoğu zaman birbiriyle sıkı ilişki içerisinde görülmektedir8.

Suç örgütleri; amaçlarına ulaşmak için devlet aygıtının içine sızarak, devlet erklerini kendi çıkarları doğrultusunda yönlendirebilmekte ve hatta bu aygıtı doğrudan kullanabilmektedir. Bürokrasi içinde etkin olabilmek için kontrol ettikleri devasa ekonomik gücü kullanan suç örgütleri, belirli bir güç elde ettikten sonra ise tam tersine bir yaklaşımla, bürokrasideki güçlerini kullanarak daha fazla ekonomik çıar elde etmeyi hedeflemektedir. Bu durum, bir kısır döngü şeklinde devam etmekte ve kartopu etkisi yaratmaktadır.

Tüm bu gerekçelerle, ister az ister çok gelişmiş olsun, tüm devletler bakımından suç örgütleriyle mücadele önemli bir mecburiyet halini

5 ÖZGENÇ, İzzet / YURTLU, Fatih, “Suçtan Kaynaklanan Malvarlığı Değerlerini Aklama Suçlarn Bakımından Teori ve Uygulamada Ortaya Çıkabilecek Sorunlara İlişkin Bir Değerlendirme", 5. Türk - Kore Ceza Hukuku Günleri Karşılaştırmalı Hukukta Ekonomik Suçlar Uluslararası Sempozyumu Tebliğler Kitabı, Editörler: İzzet ÖZGENÇ / Cumhur ŞAHIN / Faruk TURHAN, Ankara 2020, C. I, s. 449.

6 KÖROĞLU, Hasan, Çıkar Amaçlı Suç Örgütleriyle Mücadele ve Cürüm İşlemek İçin Teşekkül Oluşturmak, Ankara 2001, s. 21.

7 ÖZGENÇ / YURTLU, “Suçtan Kaynaklanan Malvarlı̆̆ı Değerlerini Aklama Suçları Bakımından Teori ve Uygulamada Ortaya Çıkabilecek Sorunlara İlişkin Bir Değerlendir$m e^{\prime \prime}$, s. 449.

8 KÜLÇÜR, İzzet Erdem, “Avrupa Konseyi Bünyesinde Oluşturulan Terörizmin Bastırılması Sözleşmelerine İlişkin Düzenlemeler", Dr. Silvia Tellenbach'a Armağan, Ankara 2018, s. 379 v.d. 
almıştır. Toplum barışını ve hukukun üstünlüğünü devam ettirme yükümlülüğü altında olan hukuki otoriteler; bir taraftan toplum barışını tüm yönleriyle sarsan suç örgütleriyle etkili mücadele etmek, diğer taraftan ise bu mücadele sırasında kullanacağı enstrümanların temel hak ve özgürlüklere orantısız müdahalesini engellemekle yükümlüdür9 . Bu durum, özellikle terör örgütlerinin gerçekleştirdiği sansasyonel ve kanlı eylemlerden sonra "güvenlik-özgürlük dengesi" olarak gündeme gelmektedir.

Bu bakımdan, hukuk devleti olma iddiasındaki meşru otoritelerin ceza hukuku sorumluluğunun başlangıcını ve kapsamını oldukça dikkatli bir biçimde belirlemeleri gerekir. Bu gerekliliğe paralel olarak, 5237 sayılı Türk Ceza Kanunu da, suç ihdas ederken ve cezai sorumluluğun sınırların belirlerken bireysel/kamusal değerlerin korunması bakımından bir denge arayışı içinde görünmektedir. TCK m. 1'in gerekçesinde; ceza kanunun amacının bireysel ve kamusal hukuki değerlerin korunması olduğu açıkça vurgulanmış ve demokratik bir devlet olmanın gereği olarak Anayasa'da yer alan temel hak ve özgürlüklerin bireysel hukuki değerlerden oluştuğu belirtilmiştir. Bu bakımdan 5237 sayılı Türk Ceza Kanunu; bir taraftan bireysel temel hak ve özgürlükleri suç ve ceza normlarıyla korumayı amaçlarken, diğer taraftan da bu korumanın aynı zamanda ilgili temel hak ve özgürlüklerin sinırlandırılması anlamına geldiğini göz önünde bulundurmuştur. Bu husus, teşebbüs sorumluluğunun düzenlendiği m. 35'in gerekçesinde açıç̧a vurgulamıştır ${ }^{10}$. Türk Kanun Koyucu; TCK m. 35'in gerekçesinde, icra hareketlerinin teşebbüs aşamasına vardığını belirlemek için "sübjektif" bir kıstasın (failin kastını şüpheye yer birakmayacak şekilde belirten hareketler) yerine "objektif" bir kıstas kullanılmasının daha isabetli olduğunu belirtmiş ve tercihini açıkça "objektif" kıstastan yana kullanmıştır. Çünkü Türk Kanun Koyucu'ya göre; teşebbüsün başlangıcını belirlemek, cezalandırılabilir eylemi

9 YURTLU, Fatih, "Suç Örgütünün Propagandasını Yapma Suçu ve Türkiye Açısından AİHM Kararlarına Yansıması", Gazi Üniversitesi Hukuk Fakültesi Dergisi, C. xx, sa. 3, y. 2016 (Temmuz), s. 431.

10 Teşebbüsün cezalandırılma sebeplerine ilişkin ayrıntılı teorik açılamalar için bkz. KAZAKER, Gözde, Ceza Hukukunda Elverişsiz Teşebbüs, Ankara 2019, s. 122 v.d. 
ve dolayısıyla ceza sorumluluğunun başlangıcını belirlemek demektir ${ }^{11}$. $\mathrm{Bu}$ da "kişi hak ve özgürlüklerin korunmasıla yakından ilgilidir". Başka bir ifadeyle, cezalandırılabilir teşebbüsün başlangıcı ne kadar öne çekilirse, kişi hak ve özgürlüklerine o kadar müdahale edilmiş ve özgürlüklerin alanı daraltılmış olur. Bu felsefeye göre; cezalandırmanın kapsamından çıkarılmış hazırlık hareketleri aşaması, temel hak ve özgürlüklerinin korunması için bir gerekliliğin ötesinde aynı zamanda bir zorunluluktur. Halbuki kanunlaşmayan "Türk Ceza Kanunu Tasarısı", 5237 sayılı TCK'dan farklı olarak hazırlık hareketleri aşamasını "sübjektif" bir ölçütle belirlemeye çalışmıştır ${ }^{12}$. Kanunlaşmayan tasarı ile kanunlaşan metnin teknik farklılıkları bir kenarı bırakılacak olsa dahi, temel hak ve özgürlüklerin sınırlandırılması hususundaki bu önemli felsefi farkın gözden kaçırılmaması gerekir. Kanaatimizce de; teşebbüs sorumluluğunun baş-

11 Suçun teşebbüs halinde kalması halinde cezalandırılabilmesini sağlayan hükümler ceza sorumluluğunun alanını genişletici mahiyet ihtiva etmektedir. ÖZGENÇ, İzzet, Türk Ceza Hukuku Genel Hükümler, 16. Bası, Ankara 2020, s. 501.

12 Hükümet tarafından meclise ilk sunulan ancak kanunlaşmayan tasarı metninin teşebbüs hükümlerini düzenleyen 37. ve 38. maddeleri şu şekildedir:

Eksik Teşebbüs

Madde 37: "Bir kimse, işlemeyi kastettiği bir cürmü, elverişli vasıta ile ve kastı şüpheye yer bırakmayacak şekilde belirten hareketlerle icraya başlayıp da elinde olmayan engelden dolayı icra hareketlerini tamamlayamamış ise, kanunda ayrı hüküm bulunmayan hâllerde, fiil ağırlaştırılmış müebbet hapis cezasını gerektirdiği takdirde onüç yıldan onbeş yıla; müebbet hapis cezasını gerektirdiği takdirde dokuz yıldan oniki yıla kadar hapis cezası ile cezalandırılır. Diğer hâllerde temel cezanın üçte ikisinden, beşte dördüne kadarı indirilir. Ancak, verilecek ceza dokuz yıl hapis cezasindan fazla olamaz.

Fail, cürmün icra hareketlerinden kendiliğinden vazgeçtĭgi ve fakat tamam olan kısım esasen bir suç oluşturduğu takdirde, sadece o suça ait ceza ile cezalandırılır".

\section{Tam teşebbüs}

Madde 38: "Bir kimse, kastettiği cürmün icra hareketlerini bitirmiş fakat elinde olmayan engelden dolayı cürmün neticesi meydana gelmemiş ise, kanunda ayrı hüküm bulunmayan hâllerde, fiil, ă̆ırlaştırılmış müebbet hapis cezasını gerektirdiği takdirde, onaltı yıldan yirmi yıla; müebbet hapis cezasını gerektirdiği takdirde onüç yıldan onbeş yıla kadar hapis cezası ile cezalandırılır. Diğer hâllerde temel cezanın yarısından beşte üçüne kadarı indirilir; ancak, verilecek ceza onüç yıl hapis cezasından fazla olamaz". Türk Ceza Kanunu Tasarısı ve Adalet Komisyonu Raporu (1/593), Dönem: 22, Yasama Yılı: 2, T.B.M.M. (S. Say1s1: 664).

Bu hükümler de açıkça göstermektedir ki kanunlaşmayan tasarı, teşebbüs ve dolayısıyla ceza hukuku sorumluluğunun başlangıcını tespit noktasında "sübjektif" kıstası benimsemiştir. 
langıcının belirlenmesi açısından "objektif sistemin" benimsenmesi daha isabetli olmuştur.

Görüldüğü gibi 5237 sayılı TCK; temel hak ve özgürlükleri korumak amacıyla, cezalandırılmayan hazırlık hareketleri alanından çıkıldığını "objektif" bir kıstasla belirlemiş ve böylece "toplumsal genel menfaatlerin korunmasıla temel hak ve özgürlüklerin korunması arasında makul bir denge" kurmaya çalışmıştır. TCK, ceza kanunlarıyla bireysel temel hak ve özgürlüklerin korunması adı altında bu özgürlüklerin ilgasına veya orantısız sınırlandırılmasına yol açacak hükümler ihdas etmemeye özen göstermiştir. Çünkü özgürlükçü bir ceza kanunu, bireysel temel hak ve özgürlükleri suç ve ceza ihdas ederek korumaya çalışırken aynı zamanda bizatihi ilgili suç normlarıyla söz konusu temel hak ve özgürlüklerin orantısız bir biçimde sınırlandırılmasını da önlemek zorundadır. Bu nedenle öyle bir ceza hukuku sistemi oluşturulmalıdır ki; bireysel temel hak ve özgürlükler hem üçüncü kişiler tarafından gelecek müdahalelere karşı, hem de bizatihi suç normu ihdas edip bunun takibatını yapan devlet erkinden gelecek orantısız müdahalelere karşı korunabilmiş olsun.

İş bu çalışmada, kısaca "güvenlik - özgürlük dengesi" olarak ifade edilen bu husus, özellikle terör suçlarına yönelik bazı hazırlık hareketlerinim müstakil suçlar olarak düzenlenmesi (önalan suçları) özelinde ele alınacaktır. Bu kapsamda; son dönemlerde gelişmiş batı demokrasilerinde yapılan kanuni düzenlemelere de yansıyan "ceza sorumlulŭ̆unun başlangıç anını öne çeken" örnekler üzerinde durulacaktır. Konuya ilişkin değerlendirmelerde, hem Türk ceza mevzuatıyla benzerlik içermesi hem de gelişmiş bir batı demokrasisi örneği olması nedeniyle Alman mevzuatı ve uygulaması incelenecektir. Söz konusu düzenlemeler incelenirken, Alman uygulamasının konuya ilişkin çeşitli kararlarına yer verilerek konunun salt teorik yönü değil uygulama yönü de değerlendirilmiş olacaktır.

\section{SUÇ TEORISII BAKIMINDAN CEZA SORUMLULUĞUNUN BAŞLANGIÇ ANININ TESPITI}

Suç; "toplumsal düzenin devamı açısından korunması gereken hukuki değerlerin açık veya bilinçli bir ihlali ya da en azından, bu değerleri korumaya 
yönelik kurallara özensizlik niteliği taşıyan insan davranışları" șeklinde tanımlanabilir13. Bununla beraber, bir davranışın suç olarak nitelendirilebilmesi ve ceza hukuku sorumluluğuna neden olabilmesi için bazı özellikleri taşıması gerekir. Bir davranışın ceza sorumluluğuna esas teşkil edebilmesi, yani "fiil" olarak telakki edilebilmesi için; insan kaynaklı, insanın yönlendirici iradesinin ürünü ve dış dünyaya yansımış olması gerekir ${ }^{14}$.

Bu genel yaklaşımın bir sonucu olarak, davranış normlarına aykırılık teşkil eden bir fiilin haksızlık olarak kabul edilebilmesi ve hukukun konusunu oluşturabilmesi için mutlaka "dış dünyaya yansımış olması" gerekir. Bir fiil şekline bürünmemiş kastın, maksadın hukukun ilgi alanına girmeyeceği birçok hukuk düzeninde kabul gören oldukça eski bir ilkedir. Örneğin Roma hukukunda, bir kimsenin düşüncesinden dolayı cezalandırılamayacağı genel bir ilke olarak kabul edilmekteydi ${ }^{15}$.

Belirli özelliklere sahip insan davranışının dış dünyaya yansımış olması, ceza sorumluğunun doğması bakımından gerekli ancak yeterli değildir. Modern suç teorileri, bir fiilin cezalandırmaya konu teşkil edebilmesi için dış dünyaya yansımış olmasının yanında, belirli bir aşamaya varmasını da şart koşmaktadır ${ }^{16}$. Kanunlarla suç olarak düzenlenen haksızlığın başlamasından tamamlanmasına kadarki evrelere "suç yolu (iter criminis)" denilmektedir ${ }^{17}$. Suç yolu olarak adlandırılan bu süreç; "karar aşaması", "hazırlık hareketleri", "icra hareketleri" ve "netice" olmak üzere dört temel evreden oluşur ${ }^{18}$.

Salt düşünme eylemi, her ne kadar bir suça yönelik olsa dahi diş dünyaya yansımadığından "fiil" olarak telakki edilemez ve ceza hukukunun konusunu oluşturamaz. Dahası, suç işlemeye yönelik bir irade ortaya konulmuş, yani suç işleme kararı verilmiş ve bu kararının icrası kapsamında birtakım hazırlık hareketlerine başlanmış da olabilir. "Ha-

13 ÖZGENÇ, Türk Ceza Hukuku Genel Hükümler, s. 174.

14 KOCA, Mahmut / ÜZÜLMEZ, İlhan, Türk Ceza Hukuku Genel Hükümler, 13. Baskı, Ankara 2020, s. 100. v.d. YURTLU, Fatih, İhmali Suçlar. Ankara Hacı Bayram Veli Üniversitesi Lisansüstü Eğitim Enstitüsü, Yayımlanmamış Doktora Tezi, Ekim 2020, s. 54.

15 "Cogitationis poenam nemo patitur". Ulpian D 48, 19, 18.

16 ÖZGENÇ, Türk Ceza Hukuku Genel Hükümler, s. 501.

17 SÖZÜER, Adem, Suça Teşebbüs, İstanbul 1994, s. 157.

18 KOCA ve ÜZÜLMEZ, Türk Ceza Hukuku Genel Hükümler, s. 416. 
zırlık hareketleri" olarak ifade edilen bu fiiller de kural olarak cezalandırılabilir mahiyette değildir ${ }^{19}$. Söz konusu hazırlık hareketlerinin ceza hukukunun konusunu oluşturması, ancak bu hareketlerin kanun koyucu tarafından müstakil bir suç tipi olarak düzenlenmesi halinde mümkündür ${ }^{20}$. Bu bakımdan, "suç işlemek amacıyla (terör) örgüt kurma, yönetme veya üye olma fiilleri", işlenmesi amaçlanan suçlar bakımından birer hazırlık hareketi niteliğinde olmasına rağmen korudukları hukuki değer göz önüne alınmak suretiyle birçok ülkenin ceza kanununda müstakil suçlar olarak düzenlenmiştir ${ }^{21}$.

İşte tam bu noktada, zaten işlenmesi amaçlanan suçlar bakımından birer hazırlık hareketi niteliğinde olan örgüt/terör suçlarında, cezalandırmanın bir miktar daha öne çekilmesinin suç teorilerinin genel ilkeleriyle çelişip çelişmediği ve dolayısıyla temel hak ve özgürlükleri ölçüsüz bir biçimde kısıtlayıp kısıtlamadığı tartışmaları gündeme gelmektedir. Bu tartışmalar; ulusal bazda "anayasalara aykırılık", uluslararası bazda ise "taraf olunan temel hak ve özgürlüklere ilişkin uluslararası antlaşmalara aykırtlık (örneğin İnsan Hakları Avrupa Sözleşmesi gibi)" ekseninde yürütülmektedir. Bunun yanında, kusur sorumluluğu esasına dayanan modern ceza hukuku yaklaşımlarının git gide önleme amacına yönelerek bir "polisistihbarat hukuku" sistemine dönüşme tehlikesi de önemli ve güncel bir tartışma olarak karşımıza çıkmaktadır.

Özellikle terör suçları bakımından cezai sorumluluk alanının diğer suçlara nazaran erkene çekilmesi eğilimi, 11 Eylül 1999 tarihinde ABD'de düzenlenen terör saldırılarıyla birlikte batı demokrasilerinin

19 ORAL, Mehmet, "Teşebbüs”, Ceza Hukuku Günleri - 70. Yılında Türk Ceza Kanunu Genel Hükümler, İstanbul 1997 (26 - 27 Mart), s. 203. ÖZGENÇ, Türk Ceza Hukuku Genel Hükümler, s. 501.

20 Bu genel kuralın üç temel istisnası vardır. Bunlar; bazı hazırlık hareketlerinin ceza kanunlarında müstakil birer suç olarak düzenlenmesi, hazırlık hareketi olan fiillerin işlenen suçun icrası bakımından şeriklik (yardım etme) niteliği taşıması ve bazı suç tiplerinde hazırlık hareketlerinin de tamamlanmış suç gibi cezalandırılmasıdır. ÖZGENÇ, Türk Ceza Hukuku Genel Hükümler, s. 506.

21 ARSLAN, Mehmet, Alman Ceza Hukukunda Suç ve Terör Örgütleriyle Bağlantılı Suçlar ve İştirak Hükümleriyle İlişkileri, Ankara 2020, s. 17; Türk Ceza Hukuku için bkz. ÖZGENÇ, Suç Örgütleri, s. 14 - 15. YURTLU, "Suç Örgütünün Propagandasını Yapma Suçu ve Türkiye Açısından AİHM Kararlarına Yansıması", s. 412. 
gündemine girmiş ve bu eğilim birçok ülkede (Almanya ${ }^{22}$ da dahil olmak üzere) mevzuata yansımıştır. Örneğin; gelişmiş bir "batı demokrasi$s i$ " olarak gösterilen İngiltere, 2005 yılında Londra Metrosu'na düzenlenen terör saldırıları sonrası mevzuat değişiklikleri yaparak oldukça tartışmalı hukuki ve fiili önlemlere başvurmuştur ${ }^{23}$. Daha yakın tarihlerde ise, Suriye iç çatışmasında taraf olan DAEŞ terör örgütünün, internet yardımıyla Avrupa ülkelerinden militan devşirmesi nedeniyle birçok Avrupa ülkesinde benzer yaklaşımlar ve tartışmalar gündeme gelmiştir.

\section{ALMAN MEVZUATINDA SUÇ ÖRGÜTLERINNE İLIŞKİN DÜZENLEMELER}

Yukarıda ifade ettiğimiz üzere, ceza hukuku sorumluluğunun gündeme gelmesi, suç fiilinin belirli bir aşamaya varmasına bağlıdır. Bu bakımdan, salt olarak suç işleme düşüncesi/kararı, ceza sorumluluğuna gidilebilmesi için yeterli değildir. Hatta suç işleme kararının icrası kapsamında, suçun işlenmesi için birtakım "hazırlık hareketleri" dahi yapılmış olabilir. Örneğin; işlenecek suçta kullanılacak suç aletleri temin edilmiş, ayrıntılı suç planı yapılmış olabilir. "Hazırlık hareketi" olarak ifade edilen bu fiiller, kural olarak ceza hukuku sorumluluğunu gerektirmez.

Modern suç teorilerine hâkim bu genel ilkeler, teşebbüs sorumluluğunun düzenlendiği Alman CK 22. ve 23. maddeleri bakımından da geçerlidir ${ }^{24}$. Bununla beraber hazırlık hareketleri, kanun koyucu tarafından müstakil birer suç olarak düzenlenmişse ceza sorumluluğu gündeme gelmektedir. İşte tam bu noktada, en çok tartışılan konuların başında "örgüt suçları" ve bunlarla bağlantılı olarak karşımıza çıkan "propaganda suçları" gelmektedir. Bu iki başlıktan daha tartışmalı ve daha güncel olan üçüncü bir başlık ise "önalan suçları" olarak da ifade edilen, hazırlık

22 Bkz. RADTKE, Henning / STEINSIEK, Mark, "Bekämpfung des internationalen Terrorismus durch Kriminalisierung von Vorbereitungshandlungen? - Zum Entwurf eines Gesetzes zur Verfolgung der Vorbereitung von schweren Gewalttaten (Referentenentwurf des BMJ vom 21.4.2008)", ZIS 9/2008, s. 383 v.d.

23 YURTLU, Suç İşlemek Amaciyla Örgüt Kurma, Kurulmuş Örgütü Yönetme veya Bu Örgüte Üye Olma, s. 34.

24 MOSENHEUER, Andreas, Urteilsanmerkung BGH, Urt. v. 14.6.2005 - 1 StR 503/04, ZIS 2/2006, s. 101. 
hareketlerinin daha erken dönemde cezalandırılmasını öngören düzenlemelerdir.

Söz konusu bu üçlü ayrım, Alman mevzuatında suç örgütlerine ilişkin düzenlemeler bakımından da rahatlıkla yapılabilir ${ }^{25}$ :

1. Suç Örgütlerine İlişkin Temel Düzenlemeler (Örgüt Suçları)

2. Devletin Güvenliğine Yönelik Ağır Suçlara İlişkin Bazı Hazırlık Hareketlerinin Cezalandırılmasına Yönelik Düzenlemeler (Önalan Suçlari) ${ }^{26}$

3. Doğrudan Suç Örgütlerine İlişkin Olmamakla Beraber, Bu Örgütler Bağlamında Gündeme Gelebilecek Propaganda Suçlarına İlişkin Düzenlemeler (Propaganda Suçları)

\section{A. Örgüt Suçlari ${ }^{27}$}

Kısaca "örgüt suçları" olarak ifade edebileceğimiz birinci kategoriyi; "suç örgütü oluşturma (Alman CK m. 129)"28, "terör örgütü oluşturma (Alman CK m. 129a)" ve "yurt dışında bir terör örgütü oluşturma (Alman CK m. 129b)" gibi temel düzenlemeler oluşturmaktadır ${ }^{29}$. Tıpkı 5237 sayılı TCK'da olduğu gibi Alman $C^{\prime}$ 'da da, örgüt kurma veya örgüte iştirak etme fiilleri birer hazırlık hareketi niteliğinde olmasına rağmen Kanun Koyucu tarafından müstakil suçlar olarak düzenlenmiştir ${ }^{30}$. Bununla beraber 2017 yılında, Avrupa Birliği hukukuna uyum kapsamında Al-

ARSLAN, Mehmet, "Recent Developments in Law of Intelligence and Crime Control with regard to Terrorism in Germany", Allahmeh Tabataba'i University Tehran, 05.03.2018, https://www.mpicc.de/de/home/arslan.html, siteye erişim tarihi: 12.01.2021. ARSLAN, Alman Ceza Hukukunda Suç ve Terör Örgütleriyle Bağlantılı Suçlar ve İştirak Hükümleriyle İlişkileri, s. 95 v.d.

27 "Vereinigungsdelikte".

28 Alman CK Madde 129: Suç Örgütlerinin Oluşturulması

"Üst sınırı en az iki yıl hapis cezasın gerektiren suçların işlenmesine yönelik faaliyeti veya amacı olan bir örgütü kuran veya bu örgüte üye olarak iştirak eden kişi, beş yıla kadar hapis cezası veya adli para cezasıyla cezalandırllır. Böyle bir örgüte yardım eden veya onun için üye veya yardım eden (üye) kazandırmak için propaganda yapan kişi, üç yıla kadar hapis cezası veya adli para cezasıyla cezalandırılır".

29 ARSLAN, Alman Ceza Hukukunda Suç ve Terör Örgütleriyle Bağlantılı Suçlar ve İştirak Hükümleriyle İlişkileri, s. 16 v.d.

30 WEIßER, Bettina, "Der "Kampf gegen den Terrorismus" - Prävention durch Strafrecht?", JZ 2008, s. 390. 
man CK'da örgüt tanımına yönelik bazı değişiklikler yapılmış ve böylece örgüt kavramının biraz daha genişletilmesi amaçlanmıştır ${ }^{31}$.

Bu açıklamalar ışı̆̆ında, Alman $\mathrm{CK}^{\prime}$ da suç örgütlerine ilişkin temel düzenlemelerin Türk ceza mevzuatındaki düzenlemelerle benzerlik arz ettiğini söylemek mümkündür. Türk Ceza Kanunu m. 220'de "suç işlemek amacıyla örgüt kurma, yönetme ve üye olma suçları", m. 314'te "suç işlemek amacıyla silahlı örgüt kurma, yönetme ve üye olma suçları" ve nihayetinde 3713 sayılı Terörle Mücadele Kanunu (TMK) m. 7'de "terör örgütü kurma, yönetme ve üye olma suçları" düzenlenmiştir.

Alman CK'nın suç örgütlerine ilişkin hazırlık eylemlerinin cezalandırma kapsamına alması ve bu suçun soyut bir tehlike suçu olarak düzenlenmesi, tipik suç fiilini oluşturan eylemlerin gündelik eylemlerden ayırt edilmesinde bazı zorlukları da beraberinde getirmektedir. Konuya ilişkin olarak BGH kararına konu bir olay şu şekilde gerçekleşmiştir: Bir internet sitesinde yer alan forum kısmında, El Kaide terör örgütünün Irak'ta çekilen ve örgüt militanlarının bir kişinin başını keserek insanları "cihada" çağırmasına ilişkin bir video yayınlanmıştır. Alman istinaf mahkemesi (OLG); söz konusu fiili gerçekleştiren sanıkları, "terör örgütü oluşturma (Alman CK m. 129a)" suçunun seçimlik hareketlerinden "örgüte üye veya yardım edecek kişi kazandırmak için propaganda yapmak (Alman CK m. 129a-5)" bağlamında sorumlu tutmuştur. Alman Yüksek Mahkemesi BGH (Bundesgerichtshof) ise özetle; ilgili videoların yayınlandığ 1 foruma sadece kayıtlı üyelerin girebildiğini, bu videodaki propagandanın örgüte doğrudan üye kazandırma ya da destek olma sonucunu doğurmayacağını, Alman CK m. 129a'daki hükümlerin uygulanabilmesi için soyut olarak bir sempati ya da örgütün amacının övülmesinin yeterli olmayacağı ifade etmiştir. Sonuç olarak nihai kararında BGH, söz konusu videonun internet üzerinde ilgili forumda yayınlanmasının Alman CK m. 129a bakımından mahkûmiyet için yeterli olmayacağına hükmetmiştir ${ }^{32}$.

312017 yılında yapılan bu değişiklikler sonrası örgüt suçunun unsurlarına ilişkin ayrıntılı bilgi için bkz. ARSLAN, Alman Ceza Hukukunda Suç ve Terör Örgütleriyle Bağlantılı Suçlar ve İştirak Hükümleriyle İlişkileri, s. 20 v.d.

32 BGH - 3 StR 314/12, 20.09.2012, https://www.hrr-strafrecht.de/hrr/3/12/3-314-12.php . Siteye erişim tarihi: 13.01.2021. 
Konuya ilişkin olarak yapılan bir diğer teknik tartışma ise, terör örgütlerinin "salt olarak propagandasının yapılmasının ya da örgütün amaclnın övülmesinin" Alman CK m. 129a bağlamında cezalandırılabilir olup olmadığıdır. Alman ceza mevzuatında 2002-2003 yıllarında yapılan değişikliklerden sonra, salt olarak bir terör örgütünün amacının övülmesi veya propagandasının yapılması artık cezalandırılmamaktadır ${ }^{33}$. Bu bakımdan 2002 ve 2003 yıllarında yürürlüğe giren kanuni değişikliklerle birlikte şu an için, salt olarak terör örgütünün propagandasına yönelik fiillerin Alman CK m. 129a kapsamında değerlendirilemeyeceği kabul edilmektedir. Bu bağlamda özellikle DAEŞ terör örgütüne ilişkin bazı kararlarda istinaf mahkemeleri Alman CK m. 129a'ya dayanarak mahkûmiyet hükmü kurmuşlar ise de temyiz mercii BGH, söz konusu mahkûmiyet hükümlerinin hemen hepsini bozmuştur. Konuya ilişkin bozma kararlarında BGH; terör örgütüne sempati duymak veya salt olarak örgütün amacını övmek şeklindeki fiillerin ceza hukuku sorumluluğu gerektirmeyeceğini vurgulamaktadır. BGH'ya göre; Alman CK m. 129a'daki suç tipinden dolayı failleri sorumlu tutabilmek için, örgüte somut bir şekilde üye kazandırılması veya fiili olarak (somut bir suçla bağlantılı olarak) örgüte destek verilmesi gerekir. Dolayısıyla, "salt olarak örgütün amacının ya da kendisinin propagandasının yapılmasında", örgüte doğrudan üye kazandırmak ya da somut bir suçla bağlantılı olarak destek vermeye yönelik kesin bir sonuç çıkarılamayacağından, ilgili fiiller bakımından Alman CK m. 129a hükümlerince faillerin cezai sorumluluğuna gidilememesi gerekir. Meri mevzuat ve uygulama bu şekilde olmakla beraber; son yıllarda 2002 değişikliklerinden önce olduğu gibi, salt propaganda fiillerinin cezalandırılmasına yönelik birtakım girişimlerin olduğu da kamuoyuna yansımaktadır ${ }^{34}$. Fakat söz konusu girişimlerden herhangi biri şu an için kanunlaşmış değildir ${ }^{35}$.

33 Süddeutsche Zeitung (online), 17.05.2010, "Allgemeine Aufrufe zum Dschihad nicht mehr strafbar", https://www.sueddeutsche.de/politik/bgh-allgemeine-aufrufe-zumdschihad-nicht-mehr-strafbar-1.318482. Siteye erişim tarihi: 12.01.2021.

34 Bkz. Frankfurter Allgemeine (online), 14.4.2016, "Koalition verständigt sich auf Integrationsgesetz und

Sicherheitspake", http://www.faz.net/aktuell/politik/inland/koalitionsgipfel-zu-fluechtlingen-antiterror-kampf-14177429.html. Siteye erişim tarihi: 12.01.2021. Welt (online), 10.09.2014. "Offene Sympathie für Terror soll strafbar werden", von Martin Lutz, 
BGH, Alman CK m. 129b'de yer alan suç tipindeki “örgüte destek vermek veya üye kazandırma" fiilleri yönünden yurt dışında faaliyet gösteren terör örgütleri ile Avrupa Birliği sınırları içerisinde faaliyet gösteren terör örgütleri arasında net bir ayrım da yapmaktadır. Çünkü Alman CK m. 129b'deki hüküm; yabancı ülkedeki terör örgütleri bakımından yarg1lama yapılabilmesi için fail ya da mağdurun Alman vatandaşı olması ve Alman Adalet Bakanlığı'nın izni şartlarını aramaktadır ${ }^{36}$. Görüldüğü üzere Alman CK m. 129b'de soruşturma iznine ilişkin bir düzenleme de mevcuttur. $\mathrm{Bu}$ düzenlemeye göre; bu tip fiiller bakımından yargılama izni somut bir olaya ilişkin olarak verilebileceği gibi, belirli bir örgütle bağlantılı olarak, sonradan işlenecek suçlar bakımından genel (bir izin) olarak da verilebilir. Örneğin; Alman Federal Adalet Bakanlığı bir kararla, DAEŞ terör örgütü bakımından yurt dışında işlenen tüm terör eylemleri için yargılama izni verebilecektir.

1976 yılında yürürlüğe giren Alman CK m. 129a hükmü, terör örgütleri bakımından salt olarak propaganda yapmayı suç olarak tanımlanmışken; 2002-2003 değişiklikleriyle birlikte (Kırmızı Yeşil Koalisyonu - SDP ve Yeşiller Partisi tarafından yapıldığı için Rot-Grün olarak ifade edilmektedir) "werbung" ifadesi suç tanımından çıkarılmıştır. 1976 yılında yürürlüğe konulan bu hüküm esas olarak, radikal sol terör örgütü " $R A F$ " ile mücadele için getirilmiştir ${ }^{37}$. O dönemde, RAF sempatizanlarının bir evin duvarına boyalarla " $R A F$ " yazması cezalandırılmış, bu da özellikle düşünce özgürlüğü bakımından Alman kamuoyunda ciddi

https://www.welt.de/politik/deutschland/article132063910/Offene-Sympathie-fuerTerror-soll-strafbar-werden.html, siteye erişim tarihi: 12.01.2021.

35 Bazı eyalet hükümetlerinin terör faaliyetlerine yönelik önleyici mekanizmalar için hazırlık yaptığı da ifade edilmektedir. Welt (online), 16.02.2018. "NRW bringt neues Sicherheitspaket gegen Terror auf Wen ", https://www.welt.de/regionales/nrw/article173664358/NRW-bringt-neues-

Sicherheitspaket-gegen-Terror-auf-den-Weg.html, siteye erişim tarihi: 12.01.2021.

36 Her ne kadar tutuklama koruma tedbirinin yerindeliğine ilişkin bir karar olsa da, özellikle yurt dışındaki terör faaliyetleri bakımından failin Alman vatandaşı olması durumunda Alman CK m. 129a hükmünün "büyük olasılıkla uygulanacă̆ına" yönelik değerlendirmeler içeren karar için bkz. BGH- AK 18/11, Beschluss vom 15. November 2011, https:/www.hrr-strafrecht.de/hrr/2/11/ak-18-11.php, siteye erişim tarihi: 12.01.2021.

37 "Werbung für Terrororganisationen:Muss Sympathie strafbar sein?", 30.09.2014, von Christian Rath, http://www.taz.de/!5032135/, siteye erişim tarihi: 12.01.2021. 
tartışmalara yol açmıştır. Bununla beraber 1999 yılında gerçekleşen 11 Eylül saldırılarına tepki olarak 2002 yılında, "yabancı" terörist grupları da kapsayan ceza kanununun 129b paragrafı yürürlüğe sokulmuştur. Alman CK m. 129b hükmü yürürlüğe konulurken, bir taraftan da m. 129a paragrafındaki hükümler hafifçe liberalleştirilmiştir. Bu değişiklikle beraber artık, "salt sempati içerikli propaganda fiilleri" cezalandırılmamakta; ancak örgütlere "doğrudan üye veya destekçi kazandırmaya yönelik propaganda" faaliyetleri cezalandırılmaktadır ${ }^{38}$. Bu değişikliklerden sonra; özellikle etkili bir propaganda işlemi olan şiddet içerikli (kafa kesme) video ve fotoğrafları paylaşmak "unterstützen"(129a/5) - destek olma" fiili olarak kabul edilip cezalandırabiliyorken, yukarıda paylaştığımız son BGH kararları göstermektedir ki; artık salt bu tip videoların paylaşılması bu kapsamda değerlendirilmemekte ve cezalandırılmamaktadır. Bu bakımdan konuya ilişkin olarak BGH'nın önemli bir içtihat değişikliğine gittiğini söylemek mümkündür.

Alman mevzuatında suç örgütlerine ilişkin temel düzenlemelere ilişkin uygulamalar çalışmamızın doğrudan konusunu oluşturmadığından, bu aşamada daha fazla ayrıntılarına girmiyoruz. Çünkü temel hak ve özgürlüklerin orantısız bir biçimde kısıtlanması çerçevesinde temel tartışma konuları, örgüt suçlarına ilişkin temel düzenlemelerden daha çok ikinci ve üçüncü kategoriyi oluşturan "önalan suçları" ve "propaganda suçlarıdır".

\section{B. Önalan Suçlari ${ }^{39}$}

Kısaca "önalan suçları" olarak ifade edilen ve çalışmamızın da esasını oluşturan bu kategoriyi, 30.07.2009 tarihinde Alman CK'ya eklenen ve 2015 yılında kapsamı oldukça genişletilen düzenlemeler oluşturmak-

Bu değişiklikler, dönemin "Terörist Avcısı" olarak nitelendirilen Federal Başsavcısı Rainer Griesbaum tarafından dahi olumlu karşılanmıştır. Başsavcıya göre; "bu değişiklikle beraber ceza hukuku gereksiz ve geniş bir alandan kurtarılmıştır. Böylece uygulama, gerçek terör faaliyetleriyle mücadeleye odaklanma imkân bulmuştur". "Interview Bundesanwalt Rainer Griesbaum / Dschihad-Werbung ist strafbar", 24.02.2009, von Christian Rath, http://www.taz.de/!5167298/, siteye erişim tarihi: 12.01.2021. 
$\operatorname{tad}^{40}{ }^{40}$. Bu düzenlemelerin ihdas edilmesinin arkasında yatan temel gerekçe; suç örgütlerinin artık sadece kurmak, üye olmak, üye-yardımcı kazandırma veya yardım etme şeklindeki seçimlik hareketlerden oluşan (suç örgütü oluşturma - Alman CK m. 129 ve terör örgütü oluşturma - Alman CK m. 129a) faaliyetlerle sinırlı kalmadığı, salt olarak bunlara indirgenemeyeceği düşüncesidir. Bu yaklaşıma göre; değişen ve gelişen örgütlü suçluluk metotlarına karşı ceza hukukundaki klasik suç örgütü düzenlemeleriyle mücadele edilmesi mümkün değildir. Bu nedenle, özellikle devlet/toplum güvenliğine karşı ağır tehdit oluşturan örgüt suçlarıyla bağlantılı bazı hazırlık hareketlerinin müstakil suçlar olarak düzenlenmesi gerekmektedir.

Alman CK'da yer alan ve "önalan suçları" olarak nitelendirilebileceğimiz suç tipleri ise şunlardır:

- Devlet güvenliğini ağır bir tehlikeye düşürecek cebir ve şiddet suçuna hazırlık yapma (m. 89a)

- Devlet güvenliğini ağır bir tehlikeye düşürecek cebir ve şiddet suçunu işlemek için bağlantı/ilişki kurma (m. 89b)

- Terörizmin finansmanı (m. 89c)

- Devlet güvenliğini ağır bir tehlikeye düşürecek cebir ve şiddet suçunu işlemek için yönlendirme (m. 91)

Söz konusu kanuni düzenlemelerin çoğunda "terör" ibaresi doğrudan yer almasa da, ilgili düzenlemelerin genelinden ve kanunlaştırma süreçlerinden bu suç tiplerinin temel olarak terör örgütleri ve faaliyetlerine yönelik olduğu anlaşılmaktadır. Bu kanuni düzenlemeler, özellikle Alman CK m. 129a ve 129b'de tanımlanan örgüt suçlarının kapsamı dışında kalabilecek ancak örgütle bağlantılı birtakım fiilleri cezalandırmayı amaçlamaktadır. Daha önce de vurguladı̆̆ımız üzere, bu yeni düzenlemelerin arkasında yatan temel felsefe; terör örgütlerinin geliştirdikleri yeni suç işleme metotları karşısında klasik ceza hukuku düzenlemeleri-

$40 \quad$ BUTZLER, Volker, Staatsschutz mittels Vorfeldkriminalisierung. Eine Studie zum Hochverrat, Terrorismus und den schweren staatsgefährdenden Gewalttaten. Baden-Baden 2017, s. 245 v.d.

2008 yılında başlayan kanunlaştırma ve hazırlık süreçleri için bkz. RADTKE / STEINSIEK, "Bekämpfung des internationalen Terrorismus durch Kriminalisierung von Vorbereitungshandlungen?, s. 383 v.d. 
nin yetersiz kaldığına yönelik kabuldür. Bu düzenlemeler sayesinde, örgüt faaliyeti kapsamında işlenen ancak çeşitli hukuki veya fiili nedenlerle cezalandırılamayan fiiller bakımından oluşan hukuki boşluklar giderilmiş olacaktır ${ }^{41}$.

Yukarıda saydığımız ve önalan suçları kapsamında kalan düzenlemelerden "devlet güvenliğini ağır bir tehlikeye düşürecek cebir ve şiddet suçuna hazırlık yapma (m. 89a) ve bu suçları işlemek için bağlantı kurma (m. $89 b)^{\prime \prime 4}$, ceza sorumluluğunun erkene çekilmesi konusunda daha net

41 ARSLAN, Alman Ceza Hukukunda Suç ve Terör Örgütleriyle Bağlantılı Suçlar ve İştirak Hükümleriyle İlişkileri, s. 95 - 96.

Alman CK m. 89a: Devleti Ağır Bir Şekilde Tehlikeye Düşüren Bir Şiddet Fiilini Hazırlamak

“(1) Her kim devleti ağır bir şekilde tehlikeye düşüren bir şiddet fiilini hazırlarsa altı aydan on yıla kadar hapis cezasıyla cezalandırılır. Devleti ağır şekilde tehlikeye düşüren bir şiddet fiilinden; $m$. 211 veya $m .212$ anlamında hayata karşı veya $m$. 239 a veya 239 b anlamında kişi özgürlüğüne karşı, duruma göre bir devletin veya uluslararası bir organizasyonun varliğı veya güvenliğini zedelemeye veya Federal Alman Cumhuriyetinin anayasal esaslarmı bertaraf etmeye veya sarsmaya yönelik belirlenmiş veya buna elverişli bir suç anlaşılır.

(2) Birinci fikra, failin devleti tehlikeye düşüren ağır şiddet eylemini, sadece, şu şekillerde hazırlaması halinde uygulanır;

1. Birinci fikrada belirtilen suçların işlenmesine hizmet eden, ilgili fillerin icrası için gereken özel düzeneklerin veya başkaca becerilerin; başka birine veya kendisine ateşli silahları, patlayıcı maddelerin veya patlayıcı veya yanıcı düzeneklerin, nükleer yakıt veya başkaca radyo aktif maddelerin, zehir içeren veya ortaya çıkarabilen maddelerin üretilmesi veya bunlarla muamele edilmesi bakımindan ders vermesi veya kendine ders verdirtmesi ile edinmesi,

2. 1. numarada tasvir edilen cinsten silahlarn, maddelerin veya düzeneklerin üretilmesi, kendine veya başka birisine să̆lanması, muhafaza edilmesi veya başka birine bırakılması veya

3. 1. numarada tasvir edilen cinsten silahlarn, maddelerin veya düzeneklerin üretilmesi için esasl olan şeyleri veya maddeleri kendine sağlanması veya muhafaza edilmesi.

(2a) Birinci fikra, failin devleti tehlikeye düşüren ağır şiddet eylemini, bu eylemi veya ikinci fikranın birinci numarasındaki eylemleri işlemek amactyla Federal Almanya Cumhuriyeti'nden, ikinci fikranın birinci numarasındaki derslerin gerçekleşeceği bir devlete gitmek için çıkış yapmaya teşebbüs etmesi halinde de uygulanır.

(3) 1. fikra hazırlığın yurt dışında işlenmesi halinde de geçerlidir. Hazırlı̆̆ın Avrupa Birliği'ne üye ülkelerin dışında işlenmesi halinde, bu husus, sadece hazırlı̆̆ın bir Alman tarafindan veya yaşamın yurt içinde idame ettiren bir yabancı tarafindan veya hazırlanan devleti tehlikeye düşürecek ağır şiddet eylemin yurt içinde veya bir Alman tarafindan veya bir Almana karşı işlenecek olması halinde geçerlidir".

43 Alman CK Madde 89b: Devleti Tehlikeye Düşürecek Ağır Bir Şiddet Eylemini İşlemek İçin Bağlantı Kurma 
örneklerdir. Her iki suç tipi bakımından da, güvenliği ağır bir tehlikeye düşürülecek devletin Alman Devleti olması şart değildir. Bir başka ifadeyle, yabancı bir devletin güvenliğini tehlikeye düşürmek amacıyla bu kapsama giren fiillerin işlenmesi halinde de ilgili suç tipleri oluşacaktır ${ }^{44}$. Bu bağlamda, "patlayıcı madde yapımı konusunda eğitim vermek, eğitim almak, bunların üretimini sağlamak, depolamak veya bu kapsamda eğitim almak için yurt dışına gitmeye teşebbüs etmek" gibi fiiller Alman CK m. 89a kapsamında değerlendirilecek iken; örgütle herhangi bir hiyerarşik ilişkisi olmayan ve hatta örgüte doğrudan yardım etme amacı dahi olmayan kimselerin bazı suçları işlemek için üçüncü kişilerle bağlantı kurması ise Alman CK m. 89b kapsamında mütalaa edilecektir ${ }^{45}$.

Alman CK m. 89a ve 89b düzenlemeleri, kural olarak yabancı devletlere karşı işlenen fiilleri de kapsamaktadır. Ancak çalışmamızda da bir kısmına yer verdiğimiz yargı kararlarında, Alman Yüksek Mahkemesi BHG'nın özellikle yabancı ülkeler söz konusu olduğunda ilgili düzenlemeleri dar yorumlama eğiliminde olduğu görülmektedir. BGH'ya göre; söz konusu hükümlerin ihdas edilme amacı, yabancı devletlerin iç güvenliğini sağlamak değildir. Bu nedenle, özellikle Avrupa Birliği d1şında kalan ülkelerde devam etmekte olan iç çatışmalar bakımından, söz konusu kanuni düzenlemelerin uygulanmasında çok daha dikkatli olmak gerekir. Buna karşılık, ilgili maddelerde tanımlanan suç fiillerinin

“(1) m. 89af. 2 Nr. 1 anlamında devleti tehlikeye düşürecek ă̆ır bir şiddet eylemini işlemek için ders almak maksadıyla, m. 129a anlamında bir örgütle ( $m$. $129 b$ bă̆lamında da) ilişki kuran veya bu ilişkiyi sürdüren kişi üç yıla kadar hapis veya para cezasıyla cezalandırılır.

(2) Birinci fikra hükmü, eylemlerin münhasıran hukuka uygun mesleki ve görevsel yükümlülüklerin yerine getirilmesine hizmet etmesi halinde, geçerli değildir.

(3) Birinci fikra, bağlantı kurmanın veya sürdürmenin yurt dışında gerçekleşmesi halinde de geçerlidir. Avrupa Birliğine üye ülkelerin dışında ise, sadece, bağlantı kurmanın veya ilişkiyi sürdürmenin bir Alman tarafından veya yaşamın yurt içinde idame ettiren bir yabancı tarafindan işlenmesi halinde geçerlidir".

44 Alman Yüksek Mahkemesi BGH birçok kararında, özellikle DAEŞ örgütüne katkı niteliğindeki fiiller bakımından ilgililer hakkında, Suriye Devleti'nin güvenliğini ağır bir biçimde tehlikeye düşürdüklerinden bahisle Alman CK m. 89a ve 89b uyarınca mahkûmiyet hükmü kurmuştur. Bkz. BGH - StB 13/19, Beschluss v. 13.06.2019 OLG (Celle), HRRS 2019 nr. 819, kn. 37, https://www.hrr-strafrecht.de/hrr/2/19/stb13-19.php , siteye erişim tarihi: 14.01.2021.

45 ARSLAN, Alman Ceza Hukukunda Suç ve Terör Örgütleriyle Bağlantılı Suçlar ve İştirak Hükümleriyle İlişkileri, s. 97 - 98. 
Almanya veya Avrupa Birliği sınırlarına somut bir yansıması olduğunda, bu hükümlerin uygulanması daha olasıdır ${ }^{46}$.

2009 yılındaki "Güvenlik Paketiyle" yürürlüğe giren ACK m. "89a (devlet güvenliğini ă̆ır bir tehlikeye düşürecek cebir ve şiddet suçuna hazırlık yapma)", " $m$. $89 b$ (devlet güvenliğini ă̆ır bir tehlikeye düşürecek cebir ve şiddet suçunu işlemek için bağlantlilişki kurma)" ve "m. 91 (devlet güvenliğini ă̆ır bir tehlikeye düşürecek cebir ve şiddet suçunu işlemek için yönlendirme)" düzenlemeleri, bir suç işleme yöntemi veya yönlendirmesi içeren faaliyetleri cezalandırmaktadır. Söz konusu maddelerdeki düzenlemeler, propaganda suçlarına benzese de burada cezalandırılan somut bir övme değil, " $m$. 89a'da ifade edilen ă̆ır suçların işlenmesi bakımından yöntem gösterme ya da doğrudan yönlendirme" fiilleridir. Dolayısıyla, salt propaganda niteliğindeki fiiller bu maddeler uyarınca cezalandırılmayacaktır. Bu düzenlemelerle aslında, devlet güvenliğini ağır tehlikeye düşürecek suçlara yönelik "yardım" fiillerinin cezalandırılması amaçlanmış görülmektedir.

Buna karşılık, söz konusu düzenlemeler bakımından tartışma yaratan temel husus; zaten birer hazırlık hareketi niteliğinde olan örgüt suçlarında ceza sorumluluğu başlangıç anının daha da erkene çekilmesinin mümkün olup olmadığıdır. Bir başka ifadeyle, söz konusu bu kanuni düzenlemelerle, bir nevi "hazırlık hareketlerinin hazırlığını oluşturan fiillerin" cezalandırılıyor olmasının, ceza hukukunun temel ilkeleri ve hukuki güvenlik ilkesi ile bağdaşıp bağdaşmadığıdır.

Örneğin; Alman CK m. 89a/2a hükmü bir kimsenin, şiddet eylemini gerçekleştirmeye yönelik bomba yapımı gibi fiilleri öğrenmek amacıyla Federal Almanya Cumhuriyeti'nden eğitimin gerçekleşeceği bir devlete "gitmek için çıkış yapmaya teşebbüs etmesi" halinde de cezaland1rılmasını mümkün kılmaktadır. Bu bakımdan söz konusu düzenlemeler ile "zaten hazırlık hareketi olan örgüt suçuna ilişkin yardım fiillerine teşebbü-

46 BGH başka bir kararında, benzer şekilde Alman CK m. 129a bakımından da Avrupa Birliği sınırlarının dikkate alınması gerektiğini, AB topraklarına yansımayan eylemler içinse bu hükmün daha dar yorumlanması gerektiğini ifade etmiştir. Buna karşılık BGH, Alman CK m. 129b'nin yurtdışında icra edilen terör faaliyetleri hakkında da rahatlıkla uygulanabileceği kanaatindedir. BGH - AK 52/16, Beschluss vom 6. 10. 2016, https://lexetius.com/2016,3316, siteye erişim tarihi: 13.01.2021. 
sün" cezalandırıldığ1 rahatlıkla söylenebilir. Böyle bir olayda failin cezalandırılan fiili, "yurt dışına çıkmaya teşebbüs etmekten" ibarettir. Alman CK m. 89a/2a' daki hükümle; zaten birer "hazırlık hareketi olan suç örgütü fiillerine yönelik hazırlık hareketlerine" teşebbüs cezalandırılarak, cezalandırmanın alanı üç derece daha erkene çekilmektedir. Buradaki yurt dışına çıkış amacı her ne kadar gayri meşru da olsa, bu gayri meşru amacın somut bir fiile dönüşüp suçun konusu bakımından bir zarar ya da en azından zarar tehlikesi yarattığını söylemek çoğu zaman mümkün değildir. Bu yüzden, böyle bir durumdaki kişinin cezalandırılması, fiil ve kusur sorumluluğu esasını benimsemiş demokratik hukuk sistemleriyle bağdaşmamaktadır. Burada tabiri caiz ise daha kişinin yalnızca tasavvurunda bulunan "suç işleme düşüncesi" cezalandırılmaktadır.

Karşıt yönde görüşler olmakla birlikte Alman doktrininde de, "güvenlik" adına da olsa ceza sorumluluğunu bu şekilde oldukça öne çeken düzenlemelerin Alman ceza hukuku dogmatiği ve temel hak ve özgürlükler bakımından öngörülen güvenceler bakımından ciddi anlamda sorunlu olduğu ifade edilmektedir ${ }^{47}$. Hakeza, önalan suçlarına ilişkin söz konusu düzenlemelerle Alman ceza hukukun kusur temeline dayanan "fiil ceza hukuku sorumluluğu (Tatstrafrecht)" anlayışından uzaklaşılarak, failin tehlikeliliği esasında dayanan ve daha çok suçun önlenmesini hedefleyen "önleyici ceza hukuku (Präventionsstrafrecht)" anlayışına kayıldığ ${ }_{1}$ ifade edilmektedir ${ }^{48}$. Bu gerekçelerle, yeni ihdas edilen bu suç tiplerinin Alman Anayasasına aykırı olduğu ileri sürülmektedir ${ }^{49}$.

Konunun bir bütün olarak değerlendirilebilmesi için, Alman uygulamasının konuya ilişkin yaklaşımına da kısaca değinmek gerekir. BGH önüne gelen olay özetle şu şekilde vuku bulmuştur: Almanya'da eşinden boşanan ve sonradan Müslüman olan bir kadın, iki çocuğunu da yanına alarak internet üzerinden tanıştığı ve DAEŞ’e yakın olduğu

47 BUTZLER, Staatsschutz mittels Vorfeldkriminalisierung, s. 246.

48 WEIßER, Bettina, "Uber den Umgang des Strafrechts mit terroristischen Bedrohungslagen". ZStW 121/2009, s.153. Ceza hukukunda "güvenlikçi" anlayışlara ne kadar yer verilebileceğine ilişkin bir değerlendirme için bkz. HASSEMER, Winfried, "Sicherheit durch Strafrecht", HRRS 4/2006, s. 130 vd.

49 ZWEIGLE, Thiemo Alexander. Gesetzgeber im Konflikt zwischen Rechtsstaatlichkeit und Terrorismusbekämpfung. Eine Untersuchung zu § 89a Abs. 2a StGB. Baden - Baden 2020, s. 447 v.d. 
bilinen bir adamın yanına Suriye'ye gitmiştir. Bu yolculuk sırasında Türkiye topraklarından da geçiş yapan kadın, Suriye' de DAEŞ sempatizanları arasına karışarak bölgede silahlı eğitim almıştır. Durumun Alman makamları tarafından tespit edilmesinden sonra, kadın fail hakkında "devlet güvenliğini ağır bir tehlikeye düşürecek cebir ve şiddet suçuna hazırlık yapma (Alman CK m. 89a)" suçu kapsamında dava açılarak yargılama yapılmıştır. Yapılan yargılama neticesinde BGH, birazdan ifade edeceğimiz gerekçelerle sanık kadın hakkında Alman CK m. 89a hükümlerince ceza verilmesini isabetsiz bulmuştur. BGH'ya göre, Alman CK m. 89a hükmü kural olarak yabancı devletlere yönelen ağır tehlikeler bakımından da uygulanabilir. Ancak bu değerlendirmenin her somut olay bakımından ayrıca yapılması gerekir. Somut olayda sanığın her ne kadar Suriye Ordusu'yla silahlı bir çatışmaya hazır olduğu kabul edilebilirse de fiilen herhangi bir çatışmaya girmediği, silah eğitimini kendisini ve çocuklarını savunmak için almış olabileceği imkan dahilindedir. Hatta sanığın fiili çatışmalardan kaçınmak için Suriye içinde sürekli yer değiştirdiği ilk derece mahkemesinin vermiş olduğu mahkûmiyet hükmünde de açıkça ifade edilmiştir. Tüm bu gerekçelerle BGH'ya göre, somut olayda Alman CK m. 89a hükümlerinin uygulanması isabetli değildir ${ }^{50}$.

BGH'nın yaklaşımına göre; Alman CK m. 89a hükmünün ihdas edilme amacı, Alman CK m. 129a'daki aşamaya ulaşmayan ancak devletlerin iç ve dış güvenliği bakımından "ciddi" anlamda sorun oluşturabilecek fiilleri cezalandırmaktır. Alman Kanun Koyucu, küresel anlamda ciddi boyutlara ulaşan terörist eylemlerle daha etkin mücadele etmek amaciyla bu hükümleri ihdas etmiştir. Yine söz konusu kararında BGH; Alman CK m. 89a hükmünün kural olarak Almanya'daki toplulukların barış içerisinde ve bir arada yaşamalarını amaçladığını, yabancı devletlerin iç güvenliğini sağlamak amacıyla kanun yapılmasının uluslararası hukuk bakımından mümkün olmadığını da vurgulamıştır. BGH; özellikle Suriye'deki iç savaş da göz önüne alındığında, Alman CK'daki bu düzenlemelerin, Avrupa Birliği dışında kalan bir ülkede var olan silahlı

50 BGH - 3 StR 218/15, 27.10.2015 Urteil (LG München I), https://www.hrrstrafrecht.de/hrr/3/15/3-218-15.php , siteye erişim tarihi: 10.01.2021. 
grupların kendilerini savunma haklarını elinden alacak bir biçimde yorumlanamayacağının da altını çizmiştir ${ }^{51}$.

İhdas edilen yeni önalan suçlarının ortaya çıkardığı bir diğer problem ise kendini usul hukuku açısından göstermektedir. Bu düzenlemeler, soruşturma makamlarının oldukça sıradan, dıştan bakıldığında herhangi bir risk ve anormallik oluşturmayan gündelik bazı hareketler bakımından temel hak ve özgürlüklere doğrudan müdahale niteliği taşıyan koruma tedbirlerine başvurabilmesinin de önünü açmaktadır. Örneğin; bazı kimyevi/elektronik materyaller alan veya bulunduran, yurt dışına çıkan ya da üçüncü bir kişiyle herhangi bir amaçla iletişime geçen kimseler bakımından kolaylıkla telekomünikasyon yoluyla iletişimin denetlenmesi ya da bilgisayar kütüklerinin aranması gibi koruma tedbirlerine başvurulması mümkün olacaktır. Hakeza saydığımız bu basit fiillerin birçok olayda Alman CK m. 89a ve 89b'deki suçların işlenmiş veya işleniyor olmasından şüphe etmek için yeterli olduğu, manevi unsur bakımından çokta kapsamlı olmayan belirlemelere dayanılarak kabul edilmesinin de önü açlacaktır. Üstelik söz konusu fiillerin işlenmesinin öncesinde, önleyici kolluk ve istihbari faaliyetlerde bulunulması da mümkündür. Tüm bunlar birlikte düşünüldügünde, ihdas edilen bu hükümler üzerinden oldukça geniş kapsamlı alanların, katmanlı bir şekilde gözetim ve denetim altına alındığı görülmektedir ki; bu durum da temel hak ve özgürlüklerin orantısız bir biçimde sınırlandırılmasının önünü açmaktadır ${ }^{52}$.

\section{Propaganda Suçlari ${ }^{53}$}

İtalyancadan dilimize geçen bir sözcük olan propaganda; "bir öğreti, düşünce veya inancı başkalarına tanıtmak, benimsetmek ve yaymak amacıyla söz, yazı vb. yollarla gerçekleştirilen çalışma, yaymaca" anlamlarına gelmek-

51 BGH - 3 StR 218/15, 27.10.2015 Urteil (LG München I), https://www.hrrstrafrecht.de/hrr/3/15/3-218-15.php , siteye erişim tarihi: 10.01.2021.

52 SIEBER, Ulrich, "Der Paradigmenwechsel vom Strafrecht zum Sicherheitsrecht in: Tiedemann/Sieber/Burchard/Brodowski (Hrsg.)", Die Verfassung moderner Strafrechtspflege. Erinnerung an Joachim Vogel, Baden-Baden 2016, s. 356. ENGELHART, Marc / ARSLAN, Mehmet, Security Architecture in Germany, Freiburg 2019, s. 52. 
tedir ${ }^{54}$. Türk Yargıtay'1 ise bir kararında "propagandayı" şu şekilde tanımlamıştır: "Belli bir görüşün toplum içinde yayılmasını, fikir ve kanaatlerin kökleşmesini să̆lamak için bu amacın gerçekleşmesine yönelik olarak her türlü maddi ve manevi araca başvurarak telkin, teşvik ve etkide bulunmak"55.

Propaganda; belli bir amaca matuf olarak seçilen bilgilerin, çoğu zaman kaynak belirtilmeksizin yoğun bir şekilde aktarımı suretiyle belirli bir görüş veya eyleme yönelik olarak hedef grubun ikna edilmesi$\operatorname{dir}^{56}$. Fakat bu ikna, tartışma ve objektiflikten uzak bir şekilde yapılır ${ }^{57}$. Propaganda; bir şahsın veya grubun başka şahıs veya grupların tutumlarını değiştirmek, denetlemek ve onların tepkilerini kendi amaçlarına uygun tepkilere dönüştürmek amacıyla, gerektiğinde kitle iletişim araçlarını da kullanarak giriştikleri bir etkinlik olarak da tanımlanmaktadır ${ }^{58}$. Bu bakımdan internet ve sosyal medya araçlarının çok yaygın bir şekilde kullanıldığı günümüzde, bir suç ya da suç örgütünün propagandasının yapılması oldukça kolay hale gelmiştir. Bu bakımdan devletler, söz konusu vasıtalarla yapılan suç/örgüt propagandalarıyla çok daha etkili bir şekilde mücadele etme zorunluluğu ile karşı karşıyadır. Ancak devletler bu tür propaganda faaliyetleri ile mücadele ederken aynı zamanda düşünce ve düşünceyi yayma hürriyetine de orantısız bir şekilde müdahale etmemekle de yükümlüdür. Dolayısıyla bu tip durumlarda ilgili hukuki otoriteler iki taraflı bir yükümlülük arasında makul bir denge kurmak durumundadir.

Alman Ceza Kanunu'nda, "propaganda suçları" kategorisinde değerlendirilebilecek temel düzenlemeler ise şunlardır:

- Anayasaya aykırı örgütlerin propaganda araçlarının dağıtılmasi (m. 86)

54 Türk Dil Kurumu (Online) Güncel Türkçe Sözlük, https://sozluk.gov.tr/, siteye erişim tarihi: 07.12.2020.

55 YCGK, E. 1999/9-33, K. 1998/38, T. 16.3.1999. Kazanc1 İçtihat Bankası, http://www.kazanci.com/kho2/ibb/giris.htm, siteye erişim tarihi: 07.12.2020.

56 YURTLU, "Suç Örgütünün Propagandasını Yapma Suçu ve Türkiye Açısından AİHM Kararlarma Yanstması", s. 415.

57 ÇAKMUT, Özlem Yenerer, "Ceza Hukukunda Propaganda ve Düşünce Özgürlü̆̆̈̈̈", Prof. Dr. Sahir Erman'a Armağan, İstanbul, 1999, s. 138.

58 GÖKCEN, Ahmet, Halkı Kin ve Düşmanlığa Açıcça Tahrik Cürmü, Ankara, 2001, s. 21. 
- Anayasaya aykırı örgütlerin tanıtım işaretlerinin (sembollerinin) kullanılması (m. 86a)

- Suç işlemeye alenen çağrı (m. 111)

- Kamu barışını bozma (m. 125, 125a)

- Suç işleme tehdidiyle kamu barışını bozma (m. 126)

- Halkı kin ve düşmanlığa tahrik etme (m. 130)

- Suç işlemek için yol gösterme (m. 130a)

- Cebir tasviri (m. 131)

- İşlenen bir suçu övme veya meşru gösterme (m. 140) ${ }^{59}$

Propaganda suçları kapsamında değerlendirilebilecek ilgili suç tipleri, esasında salt örgüt suçlarına özgü değildir. Buna karşılık söz konusu suç tiplerinin özellikle "terör örgütleriyle" bağlantılı bir şekilde işlenmesi sıklıkla karşılaşılan bir durumdur. Propaganda suçlarına ilişkin düzenlemeler arasında, özellikle Alman CK m. 86, 86a, 130 ve 140'da tanımlanan suç tipleri ön plana çıkmaktadır. Söz konusu kanuni düzenlemeler, terör örgütlerinin propagandası bağlamında sıklıkla gündeme gelmekte ve yargı kararlarına yansımaktadır.

Konuya ilişkin olarak Alman Yüksek Mahkemesi BGH önüne gelen olay, özetle şu şekilde gerçekleşmiştir: Antika eşya ve eski kitap satışı yapan bir kişi, üzerinde Nazilerin sembolü olan gamalı haç işareti ve Adolf Hitler'in resminin bulunduğu "Mein Kampf (Kavgam)" adlı kitabın eski bir basısını satışa sunmuştur. Olayın tespit edilmesi üzerine, kitap satıcısı hakkında kamu davası açılmıs ve yargılamayı yapan ilk derece mahkemesi satıcıyı, "anayasaya aykırı örgütlerin propaganda araçlarının dağıtılması ( $m$. 86) ve anayasaya aykırı örgütlerin tanıtım işaretlerinin (sembollerinin) kullanılması ( $m$. 86a)" suçlarından mahkûm etmiştir. İlk derece mahkemesi mahkûmiyet kararında; kitabın bizatihi kendisinin bir propaganda aracı olması nedeniyle Alman CK m. 86'daki suç kapsamında, kitap kapağında bulunan gamalı haç işaretini ise Alman CK m. 86a (anayasaya aykırı örgütlerin sembolünü kullanma) kapsamında değerlendirmiştir. Kanun yolu incelemesinde ilk derece mahkemesinin kararını değerlendiren BGH ise; "iddia olunan fiilin failin mesleki faaliyeti çerçe-

59 ARSLAN, Alman Ceza Hukukunda Suç ve Terör Örgütleriyle Bağlantılı Suçlar ve İştirak Hükümleriyle İlişkileri, s. 98 - 99. 
vesinde işlendiğine" vurgu yaparak mahkûmiyet hükmünü bozmuştur. BGH'ya göre söz konusu olayda, failin ilgili suç tiplerinden cezalandırılabilmesi için gerekli olan "sosyal yeterlilik (Sozialadäquanzklausel)" oluşmamıştır ve bu nedenle sanığın beraat etmesi gerekir ${ }^{60}$.

Propaganda suçlarına ilişkin bir diğer BGH kararında ise ${ }^{61}$; iki kişi, dünyanın farklı bölgelerinde değişik şekillerde örgütlenen ve Almanya'da (yetkili mercilerin kararıla) yasaklı bulunan motorcu çetesinin ${ }^{62}$ logo ve işaretlerini taşıyan kıyafetleri giymiştir. Bunun üzerine yapılan yargılamalarda, söz konusu kıyafetleri giyen iki kişi bakımından Alman CK m. 86a hükmünün uygulanıp uygulanamayacağı tartışılmıştır. Somut olayda BGH; Anayasal düzene karşı tehdit oluşturmayan suç örgütlerinin işaretlerini taşımanın, Alman CK m. 86a bağlamında değerlendirilmesine mesafeli durmuştur. BGH'ya göre; "Alman CK m. 86a'daki hükmün getiriliş amacma uygun bir biçimde değerlendirme yapmak, düşünce ve ifade özgürlüğ̈̈nü sinırlandıran bu hükümler bakımından bir zorunluluktur". Bu sebeple, söz konusu kanuni düzenlemeleri yorumlarken, yargılamaya konu somut fiillerin oluşturduğu etki ve "sosyal yeterlilik (Sozialadäquanzklausel)" şartına azami ölçüde dikkat edilmesi gerekir.

Örgüt propagandasına ilişkin yargı makamları önüne gelen bir diğer olay ise şu şekilde cereyan etmiştir: Şarkıcı K, 1996 yılının Eylül

60 BGH - 3 StR 182/79 (S), Urt. v. 25.07.1979, https://research.wolterskluweronline.de/document/c6c8d84a-e74a-474f-83fd-19a39170a751, siteye erişim tarihi: 07.12.2020.

61 BGH - 3 StR 33/15, 09.07.2015 Urteil (LG Bochum), https://www.hrrstrafrecht.de/hrr/3/15/3-33-15.php, siteye erişim tarihi: 06.12.2020.

62 Yarg1 kararına konu olan grubun ad1 "Bandidos, Fat Mexican"dır. Bu topluluk, batı dünyasında motor kullanan kişiler tarafından kurulan ve daha çok maddi çıkar elde etmek amacıyla suç işleyen bir yapılanmadır. Bu oluşum, farklı coğrafyalarda farklı isimlerle örgütlenmiştir. Yapılanma, Almanya içinde de birçok bölgede farklı şekilde faaliyet yürütmektedir. Bu farklı yapılanmalardan bir kısmı suç organizasyonu niteliği taşımamasına rağmen, bazılarının çıkar amaçlı suç örgütüne dönüştüğü bilinmektedir. Bu gerekçeyle ilgili oluşumun ana fraksiyonu faaliyetleri Almanya' da yasaklanmıştır. Söz konusu örgütün farklı fraksiyonları tarafından giyilen yelek, şapka gibi kıyafetlerin üzerinde örgütü simgeleyen işaretler bulunmaktadır. Diğer gruplara ait işaretler, yasaklanan ana fraksiyonun işaretlerine benzemekle beraber bazı farklılıklar barındırmaktadır. Söz konusu bu farklı simgelerin ACK 86a maddesi bakımından nasıl değerlendirileceği hususu BGH kararında ayrıntılı olarak tartışılmıştır. BGH - 3 StR 33/15, 09.07.2015 Urteil (LG Bochum), https://www.hrr-strafrecht.de/hrr/3/15/3-33-15.php, siteye erişim tarihi: 06.12.2020. 
ayında, bir restoranda organize edilen etkinliğe "özel konuk" olarak davet edilir. Şarkıcı K sahnede; göçmen ve Yahudi karşıtlığı içeren şarkılar söyler, Yahudi katliamını reddeder ve bu fiilleri onaylar. Bunlara ek olarak, sahnede Nazi sloganları atar, Adolf Hitler'i selamlar ve seyircileri de bu tür aktiviteler yapmaları yönünde coşturur63. Olayın yargı mercilerinin önüne gelmesi sonucunda BGH; Nazi cinayetlerinin onaylanmasını içeren söz konusu fiillerin Alman CK m. 130 ${ }^{64}$ bağlamında mı yoksa Alman CK m. $140^{65}$ bağlamında $\mathrm{m}$ değerlendirilmesi gerektiğini tartışmıştır. BGH'ya göre; bu tür suçlar için aranması gereken "sosyal yeterlilik (Sozialadäquanzklausel)" şartı somut olay bakımından oluşmuştur. Ancak somut olayda mahkûmiyet hükmü "işlenen bir suçu övme veya meşru gösterme (Alman CK m. 140)" bağlamında değil, "halkı kin ve düşmanliğa tahrik etme (Alman CK m. 130/3)" bağlamında kurulmalıdır. Çünkü Alman CK m. 130/3 hükmü, Alman CK m. 140/2 hükmüne nazaran "özel norm" niteliğindedir ${ }^{66,67}$.

63 BGH - 3 StR 613/98, 26.02.1999 Urteil (LG Bochum), https://www.hrrstrafrecht.de/hrr/3/98/3-613-98.php3 . Siteye erişim tarihi: 10.12.2020.

Alman CK m. 130/3:

"Nasyonal Sosyalist iktidar altında işlenen ve Devletler Ceza Kanunun altıncı maddesinin birinci fikrasında tanımlanan bir hareketi, kamu barışını bozmaya elverişli bir şekilde, alenen veya bir toplantı strasında onaylayan, inkâr eden veya zararsı gibi gösteren kişi, üç yıla kadar hapis cezası veya adlî para cezası ile cezalandırılır". YENISEY, Feridun / PLAGEMANN Gottfried, Alman Ceza Kanunu - Strafgesetzbuch (StGB), 2. Baskı, İstanbul 2005, s. 226.

\section{Alman CK m. 140:}

"Her kim 138. maddenin birinci fikrasının 1 ila 4 numaralı bentlerinde ve 126. maddenin birinci fikrasında adı geçen hukuka aykırı fiillerden biri veya m. 176 fikra 3, m. 176a ve 176b, m. 177 ve 178 veya 179 fikra 3, 5 ve 6'da düzenlenen hukuka aykırı bir fiili, bu fiil işlendikten veya cezalandırlabilecek bir şekilde işlenmeğe teşebbüs edildikten sonra,

1. İsleyeni mükafatlandırır veya

2. Kamu barışını bozmaya elverişli bir şekilde alenen, bir toplantıda veya yazı ( $\mathrm{m}$. 11 fikra

3) yayarak bu suçu onaylarsa, üç yıla kadar hapis cezası veya adlî para cezası ile cezalandtrllı". YENISEY / PLAGEMANN Alman Ceza Kanunu Strafgesetzbuch (StGB), s. $239-240$.

66 BGH - 3 StR 613/98, 26.02.1999 Urteil (LG Bochum), https://www.hrrstrafrecht.de/hrr/3/98/3-613-98.php3, siteye erişim tarihi: 10.12.2020.

67 Alman CK m. 86, m. 111 ve m. 130'daki suçlara yönelik değerlendirmeler içeren farklı bir karar için bkz. BGH - 3 StR 602/14, 14.04.2005 (LG Berlin), https://www.hrr-strafrecht.de/hrr/3/14/3-602-14.php , siteye erişim tarihi: 10.12.2020. 
Uygulamada Alman CK 86 ve 86a maddelerinin, genellikle Nasyonal Sosyalizme yönelik propaganda fiilleri ve Nazi işaretleri (gamalı haç gibi) bakımından uygulama alanı bulduğu görülmektedir. Bununla beraber ilgili düzenlemeler özelinde, düşünce ve ifade özgürlüğünün kısıtlanması bakımından yargı organlarının somut olay bazlı tartışmalar yaptığı görülmektedir ${ }^{68}$. Bu suçlar bakımından BGH'nın kararlarında 1srarla bahsettiği "sosyal yeterlilik (Sozialadäquanzklausel)" şartıyla cezalandırılma alanı daraltılmaktadır. Bu uygulama ile BGH'nın kanuni düzenlemelerin düşünce ve ifade özgürlügünü orantısız bir biçimde kısıtlama tehlikesini dengelemeye çalıştığ 1 söylenebilir.

Alman CK m. 86 hükmü, ilgili makamlarca daha önceden yasaklanmış parti veya örgütlere yönelik fiiller bakımından da uygulanmaya müsaittir. Alman CK m. 86 ve 86a hükümlerinin yalnızca Alman mercileri tarafından yasaklanan örgüt veya dernekler hakkında uygulanacağ ifade edilmektedir ${ }^{69}$. Bununla beraber, örneğin $\mathrm{PKK}^{70}$ terör örgütünün işaretleri ya da sözde liderinin resimleri mevzu bahis olduğunda durum biraz daha karmaşık bir hal almaktadır. Bu tip fiiller bakımından Alman soruşturma makamlarının kasıtlı olarak pasif kaldığını söylemek mümkündür. Bu nedenle söz konusu fiiller bakımından ciddi bir takip problemi olduğu göze çarpmaktadır. Bununla beraber, soruşturmaya konu

Alman CK m. 86 ve 86a hükümleri bakımından yapılan bazı hukuki tartışmalar için bkz: BGH - 3 StR 495/01, 31. 07. 2002 (KG Berlin) https://www.hrrstrafrecht.de/hrr/3/01/3-495-01.php3 , siteye erişim tarihi: 10.12.2020.

Yurtdışında bulunan bir kimse tarafından internet üzerinden Nazi propagandası yapma fiiline ilişkin bir başka karar: BGH - 3 StR 88/14 = HRRS 2014 Nr. 1113, https://www.hrr-strafrecht.de/hrr/archiv/15-11/index.php?sz=7 , Siteye erişim tarihi: 10.12 .2020 .

ZIMMERMANN, Frank. "NS-Propaganda im Internet, § 86a StGB und deutsches Strafanwendungsrecht", https://www.hrr-strafrecht.de/hrr/archiv/15-11/index.php?sz=7 , siteye erişim tarihi: 10.12.2020.

$70 \quad$ PKK'nın suç örgütü olduğuna yönelik olarak Alman yargısı tarafından da verilmiş birçok karar mevcuttur. Bkz. BGH - 3 StR 265/13, Beschluss vom 6. Mai 2014 (OLG Hamburg), https://www.hrr-strafrecht.de/hrr/3/13/3-265-13.php , siteye erişim tarihi: 12.01.2021.

BGH - 3 StR 407/13, Beschluss vom 6. Mai 2014 (KG Berlin), https://www.hrrstrafrecht.de/hrr/3/13/3-407-13.php , siteye erişim tarihi: 12.01.2021.

BGH - AK 3/18, Beschluss v. 8. Februar 2018, http://juris.bundesgerichtshof.de/cgibin/rechtsprechung/document.py?Gericht=bgh\&Art=en\&az=AK\%203/18\&nr=81294 , siteye erişim tarihi: 12.01.2021. 
edilip ceza mahkemelerinin önüne gelen az sayıdaki olayda, yerel mahkemelerin aksine BGH'nın "cezalandırmama" yönünde bir eğiliminin olduğu da açıcça görülmektedir ${ }^{71}$.

Alman kamuoyunda benzer şekilde, özellikle El Kaide lideri Usame Bin Laden'in fotoğraflarını taşıyan ve popüler kültürün bir yansımas1 olarak görülen tişörtlerin giyilmesinin ceza sorumluluğu doğurup doğurmayacağı da tartışılmıştır. Şu an için genel kanı ve uygulama, bu tip fiillerin de ceza hukuku sorumluluğu gerektirmediği yönündedir ${ }^{72}$.

\section{DEĞERLENDİRME ve SONUÇ}

Gelişen teknolojik imkânlardan faydalanma noktasında her zaman hukuki otoritelerin birkaç adım önünde olan suç örgütleri, günün şartlarına çok hızlı adapte olmuş ve uluslararası boyutta faaliyet gösteren devasa organizasyonlara dönüşmüştür. Suç örgütlerinin yasadışı faaliyetlerden elde ettikleri gelirleri çeşitli vasıtalarla legal ekonomik sistemin içerisine kolayca dahil etmeleri, meşru ekonomik sistemler bakımından da ciddi sorunlara neden olmaktadır. Hakeza suçtan elde edilen malvarlığ 1 değerlerinin bu şekilde legal ekonomik sistemlere dahil edilmesi, çoğu zaman işlenen suçların takibini ve ceza muhakemesine konu olmasını da engellemektedir. Özellikle terör örgütleri tarafından gerçekleştirilen ve her türlü insani değerden yoksun şiddet içerikli eylemler, toplumların barış ve güven duygularını da derinden sarsmaktadır.

Görülmektedir ki; suç örgütlerinin hukuk toplumları bakımından oluşturduğu tehlike, hem çok boyutlu hem de oldukça şiddetlidir. Bu nedenle, batı demokrasileri olarak ifade edilen toplumlarda dahi, örgütlü suçlulukla mücadele kapsamında klasik ceza hukuku enstrümanlarının yetersiz kaldığı inancı günümüzde güçlenmektedir. Suç örgütleriyle mücadele noktasında oluşan bu toplumsal talepten güç olan yeni eğilim, suç örgütleriyle mücadelede yeni bir konsepte ihtiyaç olduğunu savunmaktadır. Özellikle terör örgütleri tarafından gerçekleştirilen sansasyo-

71 Aynı yönde karar için bkz. BGH - 3 StR 109/13, 28.07.2013 Urteil (LG Berlin), https://www.hrr-strafrecht.de/hrr/3/13/3-109-13.php , siteye erişim tarihi: 10.12.2020.

72 "Interview Bundesanwalt Rainer Griesbaum / Dschihad-Werbung ist strafbar", 24.02.2009, von Christian Rath, http://www.taz.de/!5167298/, siteye erişim tarihi: 11.12.2020. 
nel eylemlerden sonra toplumlarda oluşan güçlü güvenlik talepleri, birçok batı ülkesinde kanunlaştırma çalışmasına doğrudan yansımıştır. Bu yansımanın bir sonucu olarak birçok demokratik hukuk devleti, suç örgütleriyle bağlantılı bazı hazırlık hareketlerini müstakil yeni suç tipleri olarak düzenlemiş ve cezalandırılmasının yolunu açmıştır.

Buna karşlık, toplumun ekseriyetinde oluşan bu güvenlik talebini karşılamak adına yapılan kanunlaştırma çalışmalarının, anayasalar ile güvence altına alınan temel hak ve özgürlükler bakımından ortaya yeni problemler çıkardığ görülmektedir. Gerçekten de toplumda oluşan güvenlik talebini tatmin etme amacıyla yapılan kanunlaştırma çalışmalarıyla temel hak ve özgürlüklere orantısız bir şekilde müdahale edilmektedir. En azından hukuk devleti olma iddiasının bir gereği olarak, temel hak ve özgürlüklere yapılacak müdahalelerin ölçütlerini net bir biçimde saptama zorunluluğu, örgütlü suçlulukla mücadeleyi daha sıkıntılı bir hale getirmektedir ${ }^{73}$.

Bu bağlamda Almanya'da 2009 yılında “Yeni Terörle Mücadele Konsepti" kapsamında Alman Ceza Kanunu'na yeni düzenlemeler eklenmiştir. Bu düzenlemelerin kapsamı 2015 yılında daha da genişletilmiştir. Söz konusu düzenlemelerle; "devlet güvenliğini ağır bir tehlikeye düşürecek cebir ve şiddet suçuna hazırlık yapma (m. 89a) ve bu suçlarn işlemek için bă̆lantı kurma (m. 89b)" gibi fiiller, birer müstakil suç haline getirilmiştir. Kanunlaşan bu düzenlemeler; devletin güvenliğine yönelik ağır suçlar bakımından yapılan hazırlık hareketlerini cezalandırarak suç örgütlerinin geliştirdikleri yeni metotlarla mücadele etmeyi amaçlamaktadır.

Söz konusu bu düzenlemelere iki temel gerekçeyle ihtiyaç duyulduğu ifade edilmektedir: Birincisi; Alman CK m. 89a ve 89b düzenlemeleri sayesinde, Alman CK m. 129a veya 129b kapsamina girmeyen bazı

73 SANCAR, Türkan Yalçın, Çok Failli Suçlar, Ankara 1998, s. 140.

Hakeza bu durum 3713 sayılı Terörle Mücadele Kanunu'nun gerekçesinde de açıkça ifade edilmiştir. "Bir yandan Anayasanın tanıdığı temel hak ve hürriyetlere saygısı olmayan, şiddeti vasıta edinmiş terörizmle mücadele ederken, diğer taraftan çağdaş demokratik toplum düzenine ulaşmak için, şiddeti vasıta kılmayan düşünceleri ifade etme hürriyeti ile şiddeti benimsemeyen düşüncelerin örgütlenebilmesi hürriyetini kısıtlayıcı hükümlerde de iyileştirici düzenlemeler yapmak gerekmektedir". T.B.M.M. Terörle Mücadele Kanunu Tasarısı ve Adalet Komisyonu Raporu, TBMM, Dönem: 18, Yasama Yılı 4, sa. 554. 
hazırlık hareketlerinin cezalandırılabilmesine duyulan ihtiyaçtır. İkincisi; özellikle DAEŞ ve El Kaide gibi küresel terör örgütlerinin Avrupa topraklarında uyguladıkları yeni stratejilerle mücadele etmektir. Çünkü terör örgütleri, Avrupa'da yaşayan ve "Alone Wolf (Yalnız Kurt)" olarak ifade edilen kişilerle irtibata geçerek, bu kişilerin örgütün stratejilerine yönelik suç işlemesini sağlamaktadır. "Yalnız Kurt" olarak ifade edilen bu kimselerin çoğu zaman söz konusu örgütlerle aralarında hiçbir hiyerarşik ilişki de bulunmamaktadır. Bu kimseler, örgüt adına genellikle bir ya da bir kaç suç işledikleri için örgüte sürekli olarak destek sağladıkları (yardım ettikleri) da söylenemez. Hakeza, bu kimseler söz konusu kanlı eylemlerini gerçekleştirirken çoğu zaman ilgili terör örgütlerinin amaçları doğrultusunda değil, şahsi yönelim/eğilimleri ile hareket etmektedir. Dolayısıyla "yalnız kurt" olarak ifade edilen bu kişilerin, klasik örgüt suçlarına yönelik hükümler uyarınca cezalandırılması (Alman CK m. $129 b)$ çoğu zaman mümkün olmamaktadır.

Dahası, özellikle Ortadoğu'nun belirli bölgelerde oluşan siyasal krizlerden faydalanarak belirli bir ekonomik ve siyasi güce ulaşan bazı terör örgütleri (örneğin DAEŞ), internet üzerinden iletişime geçtikleri Avrupa vatandaşlarının örgütlerine katılması yönünde ikna faaliyetleri yürütmektedir. Bu kapsamda binlerce Avrupa vatandaşının çok çeşitli gerekçelerle ülkelerinden ayrılarak söz konusu terör örgütlerine katılmak için Ortadoğu'ya yolculuk yaptığı bilinmektedir. İşte hem "yalnız kurt" olarak ifade edilen bu kişilerin cezalandırılması noktasındaki hukuki boşlukları gidermek, hem de terör örgütlerine katılmak için ülkelerinden ayrılan Avrupa vatandaşlarının sayısını azaltmak amacıyla yeni "önalan suçları" ihdas edilmiştir. Sonuç olarak; söz konusu bu yeni düzenlemelerin amac1, küresel terör örgütleri ve bunların yeni suç işleme/örgüt üyesi kazanma stratejileriyle etkili bir mücadele vermektir.

Bu şekilde önalan suçları ihdas edilerek ceza hukuku sorumluluğunun oldukça erken bir ana çekilmesinin, ceza hukuku dogmatiği ve temel hak ve özgürlükler bakımından ciddi bir tehlike oluşturduğu da yadsınamaz bir gerçektir. Bu kapsamdaki hukuki tartışmaların ise farklı eksenlerde yürütüldüğü görülmektedir. İlk olarak, zaten hazırlık hareketi niteliğinde olan bazı fiillerin cezalandırılmasının biraz daha öne çekilmesinin ceza hukukunun genel ilkeleriyle bağdaşıp bağdaşmadığ1 
tartışılmaktadır. İkinci olarak, söz konusu düzenlemelerle, özellikle propaganda suçlarına ilişkin fiillerin cezalandırılmasında aşırıya gidilerek düşünce ve kanaat hürriyetinin ölçüsüz bir biçimde kısıtlanması tartışma konusu yapılmaktadır.

Kanaatimizce, bu düzenlemeler özelinde hukuk toplumlarını bekleyen en büyük tehlike; ceza sorumluk alanının bu şekilde oldukça erkene çekilmesiyle birlikte "fiil ve kusur sorumluluğu" üzerine inşa edilen modern ceza hukuku sistemlerinin yerini, kişilerin tehlikelilik halini esas alan "önleyici ceza hukuku - güvenlik hukukunun" alması ihtimalidir. Bu yaklaşımın salt olarak "tehlikelilik" haline odaklanması, orta ve hatta kısa vadede fiil ve kusur sorumluluğunu esas alan modern ceza hukuku dogmatiğini bir "polis - istihbarat hukuku" haline getirebilir ${ }^{74}$. Bu durum ise, temel hak ve özgürlüklere bizatihi "meşru otoriteler" tarafından orantısız müdahale imkânının kapısını açacaktır.

Suç işlemek amacıyla örgüt kurma, yönetme veya üye olma fiilleri işlenmesi amaçlanan suçlar bakımından birer "hazırlık hareketi" niteliğindedir. Modern suç teorilerinde, kural olarak hazırlık hareketleri cezalandırılmaz. Velev ki bu hazırlık hareketleri başlı başına bir suç tipi olarak düzenlenmiş olmasın. İşte tam bu noktada, "önalan suçları" olarak ifade edilen ve genellikle suç örgütleriyle bağlantılı olan yeni suç tiplerinin ihdası, kusur sorumluluğuna dayanan modern ceza hukuku anlayışlarını birer "güvenlik hukuku" anlayışına dönüştürdügü gerekçesiyle haklı olarak eleştirilmektedir. Zaten birer hazırlık hareketi niteliğinde olan örgüt suçlarıyla bağlantılı olarak sorumluluk alanının daha da öne çekilmesi, kaçınılmaz olarak temel hak ve özgürlüklerin ölçüsüz bir biçimde kısıtlanması sonucunu doğuracaktır. Hakeza yeni ihdas edilen önalan suçlarıyla bağlantılı olarak yürütülecek soruşturmalar dahilinde kolayca başvurulabilecek ceza muhakemesi tedbirleri de, temel hak ve özgürlüklere orantısız müdahale alanını daha da genişletmiş olacaktır. Koruma tedbirlerinin uygulanmasına ilişkin olarak yakın zaman içinde

74 Konuya ilişkin ayrıntılı tartışmalar ve görüşler için bkz. BOZBAYINDIR, Ali Emrah, "The Advent of Preventive Criminal Law: An Erosion of the Traditional Criminal Law?", Criminal Law Forum 29, s. 25 - 62 (2018). 
oldukça kötü bir tecrübe edinen Türk Toplumu'nun, bu konuda çok daha dikkatli olması gerektiğini düşünmekteyiz ${ }^{75}$.

Kanaatimizce, söz konusu hazırlık hareketlerinin "tehlikeli" olması noktasında kolluk ve istihbarat faaliyetleri yürütülebilir. Bu noktada, temel hak ve özgürlüklerin özüne dokunmamak kaydıyla bazı "önleyici kolluk tedbirlerine" başvurulması da makul görülebilir. Örneğin; terör örgütüne katılmak için örgüt üyeleriyle irtibata geçip bu amaçla yurt dışına çıkacağı tespit edilen kişinin yurt dışına çıkması idari bir kararla ya da önleyici kolluk faaliyetleri kapsamında engellenebilir. Yine bir terör örgütüyle irtibata geçip patlayıcı veya bomba yapımı konusunda "eğitim alan" kişinin iletişim araçları "istihbari amaçla ya da önleyici kolluk tedbirleri kapsamında" dinlenebilir. Zaten birçok ülkenin hali hazırdaki polis ve istihbarat mevzuatı bu tip dinlemelerin yapılmasına cevaz vermektedir.

Yine örgütlü suçlulukla mücadele kapsamında, temel hak ve özgürlüklere orantısız müdahale içermemek ve özlerine dokunmamak kaydıyla birtakım özel koruma tedbirlerine de (örneğin; telefon dinleme, gizli soruşturmacı görevlendirme gibi) yer verilebilir ${ }^{76}$. Buna ek olarak, örgütlü suç soruşturmaları söz konusu olduğunda bazı koruma tedbirlerinin süresi de uzatılabilir (örneğin; gözaltı süresinin uzatılması, tutuklama sürelerinin uzatılması, dinleme süresinin uzatılması gibi). Hakeza örgütlü suçlara ilişkin soruşturmaların gizlilik içerisinde yürütülmesi ve delil toplamada karşılaşılan zorlukları aşmak için birtakım özel soruşturma usulleri, delil toplama yöntemleri de kanunlarla düzenlenebilir ${ }^{77}$.

Fetullahçı Terör Örgütü'nün (FETÖ) kolluk ve yargı camiasına hâkim olduğu dönemlerde, örgütlü suçluluğu her kapıyı açan bir anahtar olarak kullandığını, toplumun her kesiminden kişilerin koruma tedbirleri uygulanmak suretiyle sindirilmeye çalışıldığını hatırlatmakla yetinelim.

76 Örneğin, İtalya'da Anti-Mafya Kanunu ile mafya tipi suç örgütleri ile mücadele noktasında bazı özel önleyici tedbirlere (koruma tedbirlerine) ayrıntılı olarak yer verilmiştir. NISCO, s. 454 v.d.

77 "Önalan" ifadesinin ceza hukuku literatürüne ilk olarak muhakeme hukuku bak1mından girdiği görülmektedir: "Önalan Soruşturmaları". Bu ifade ile vurgulanmak istenen, örgütlü suçluluk gibi bazı özel durumlarda kolluğa ceza muhakemesindeki genel soruşturmadan önce bir hazırlık aşaması yetkisinin verilmesi gerektiğine yönelik düşüncedir. Ayrıntılı bilgi için bkz. ÖZBEK, Veli Özer, "Organize Suçlulukla 
İfade ettiğimiz tüm bu özel idari/önleyici kolluk ve ceza muhakemesi düzenlemeleri, örgütlü suçlulukla mücadelede karşılaşılan zorluklar nedeniyle makul karşılanabilir. Fakat bunların ötesine geçilerek, sırf örgütlü suçlulukla mücadele adına suçun konusu bakımından herhangi bir somut tehlike dahi yaratmayan hazırlık hareketlerinin müstakil suçlar olarak düzenlenmesi ve doğrudan ceza hukukunun konusu haline getirilmesi kanaatimizce isabetli değildir. Bu yaklaşım; temel amacı kişi hak ve özgürlüklerini korumak olan maddi ceza hukukunun, söz konusu hak ve özgürlükleri bizzat kendisinin orantısız bir şekilde sınırlandırmasına yol açacaktır.

Dahası bu yaklaşımın kabul edilmesiyle birlikte, yalnızca maddi ceza hukuku açısından değil ceza muhakemesi açısından da önemli sorunlar gündeme gelecektir. Aslında basit birer hazırlık hareketi niteliğinde olan bazı fiillerin doğrudan suç olarak düzenlenmesiyle, yalnızca önleyici kolluk veya istihbarat faaliyetlerinin konusu olabilecek birtakım ağır tedbirler artık doğrudan ceza muhakemesinin konusu haline gelecektir. Bu durum da, ceza yargılaması sırasında kullanılacak delillerin hukuka uygun elde edilmesi zorunluluğuna yönelik birçok kanuni güvenceyi bertaraf etmiş olacaktır. Böylece ceza ve ceza muhakemesi hukuku ile önleyici kolluk - istihbarat hukuku (faaliyetleri) arasındaki kırmızı çizgiler tamamen ortadan kalkacaktır. Önalan suçlarına ilişkin söz konusu düzenlemeler olmadığı dönemlerde dahi bu kırmızı çizgiler hususunda çok da özverili olmayan kolluğun, bu düzenlemelerden sonra ne şekilde hareket edeceğini de göz önünde bulundurmak gerekir.

Tüm bu tartı̧malar ışığında vardığımız temel sonuç şu şekildedir: "Güvenlikçi paradigmanın" etkisiyle, suçun konusu ile doğrudan temas etmeyen bazı hazırlık hareketlerinin soyut tehlike suçu olarak düzenlenmesi, ceza hukukunda kusur sorumluluğu yerine tehlikelilik halini ve dolayısıyla önleme amacını ön plana çıkarmaktadır. Bu bakımdan, ceza hukukunun "güvenlikçi paradigmanın" etkisi altında kalarak münhasıran "önleme" amacına odaklanması, suç politikasını ve ceza hukuku enstrümanlarını iç güvenliği sağlamanın en kolay ve kullanışlı aracı ha-

Mücadelede Ön Alan Soruşturmaları", Dokuz Eylül Üniversitesi Hukuk Fakültesi Dergisi, sa. 4, y. 2002, s. 57 v.d. 
line getirebilir. Çalışmamızda ayrıntılı olarak incelediğimiz üzere Almanya gibi gelişmiş bir batı demokrasisinde dahi kolaylıkla değiştirilebilen kanuni düzenlemeler göstermektedir ki; ceza hukuku yerini gelecekte "polis ve istihbarat hukukuna" birakabilir.

Halbuki ceza hukukunun temel amacı hiçbir zaman salt olarak "önlemeye" indirgenemez. Çünkü önleme, kavramsal olarak ucu oldukça açık ve sınırlandırılması mümkün olmayan bir konsepttir. Modern ceza hukuku anlayışlarında ise, bu şekilde sınırlandırılması mümkün olmayan uçsuz bucaksız kavramlara ve konseptlere yer yoktur. Konuya ilişkin esas trajik nokta ise şudur: Tarihsel süreçte ceza hukukunun önleme fonksiyonunun ön plana çıkması, aydınlanma çağıyla birlikte gelişen akılcilıkla olmuştur. Buna karşın günümüzdeki "önleme konsepti", tam tersi bir yaklaşımla duygusallığın ve toplumsal güvenlik kaygılarının oluşturduğu taleple gündeme gelmektedir. Hakeza tarihsel süreçte birey odaklı ve temel haklar noktasında güvence sağlamayı amaçlayan ceza hukukunun temel felsefesi, yeni paradigmayla birlikte toplum odaklı ve güvenlik gayesiyle temel haklara yönelik güvenceleri bertaraf edebilecek niteliğe doğru evrilmektedir. Bu bakımdan, söz konusu düzenlemelere hakim olan yaklaşımın, modern suç teorileri ve ceza adaleti sistemleri bakımından oldukça tehlikeli olduğu kanaatindeyiz. 


\section{KAYNAKLAR}

ARSLAN, Mehmet, Alman Ceza Hukukunda Suç ve Terör Örgütleriyle Bağlantılı Suçlar ve İştirak Hükümleriyle İlişkileri, Ankara 2020. ARSLAN, Mehmet, "Recent Developments in Law of Intelligence and Crime Control with regard to Terrorism in Germany", Allahmeh Tabataba'i University Tehran, 05.03.2018, https://www.mpicc.de/de/home/arslan.html, siteye erişim tarihi: 12.01.2021.

BOZBAYINDIR, Ali Emrah, "The Advent of Preventive Criminal Law: An Erosion of the Traditional Criminal Law?", Criminal Law Forum 29, s. $25-62$ (2018).

BUTZLER, Volker, Staatsschutz mittels Vorfeldkriminalisierung. Eine Studie zum Hochverrat, Terrorismus und den schweren staatsgefährdenden Gewalttaten, Baden - Baden 2017.

ÇAKMUT, Özlem Yenerer, “Ceza Hukukunda Propaganda ve Düşünce Özgürlüğ̈̈", Prof. Dr. Sahir Erman'a Armağan, İstanbul 1999.

DÖNMEZER, Sulhi, “Organize Suçlulukla Mücadele”, Galatasaray Üniversitesi Hukuk Fakültesi Dergisi, Kemal Oğuzman'a Armağan, Ocak 2002, sa. 1, y.1, s. 3 - 10.

ENGELHART, Marc / ARSLAN, Mehmet, Security Architecture in Germany, Freiburg 2019.

EVIKK, Vesile Sonay, Çıkar Amaçlı Örgütlenme Suçu, 1. Bası, İstanbul 2004.

FIORENTINI, Gianluca / PELTZMAN, Sam, The Economics of Organised Crime, Cambridge University Press, 2005.

GÖKCEN, Ahmet, Halkı Kin ve Düşmanlığa Açıkça Tahrik Cürmü, Ankara 2001.

HASSEMER, Winfried, "Sicherheit durch Strafrecht", HRRS 4/2006, s. 130 - 143.

KAZAKER, Gözde, Ceza Hukukunda Elverişsiz Teşebbüs, Ankara 2019. KOCA, Mahmut / ÜZÜLMEZ, İlhan, Türk Ceza Hukuku Genel Hükümler. 13. Baskı, Ankara 2020.

KÖROĞLU, Hasan, Çıkar Amaçlı Suç Örgütleriyle Mücadele ve Cürüm İşlemek İçin Teşekkül Oluşturmak. Ankara 2001. 
KÜLÇÜR, İzzet Erdem, “Avrupa Konseyi Bünyesinde Oluşturulan Terörizmin Bastırılması Sözleşmelerine İlişkin Düzenlemeler", Dr. Silvia Tellenbach'a Armağan, Ankara 2018, s. 361 - 386.

MOSENHEUER, Andreas, "Urteilsanmerkung BGH, Urt. v. 14.6.2005- 1 StR 503/04". ZIS 2/2006, s. 99 - 104.

NISCO, Attilio, "Organized Crime In Italian Criminal Law and Practice: An Overview of Some Current Problems", Dr. Silvia Tellenbach'a Armağan, Ankara 2018, s. 445 - 458.

ORAL, Mehmet, "Teşebbüs", Ceza Hukuku Günleri - 70. Yılında Türk Ceza Kanunu Genel Hükümler, İstanbul 1997 (26 - 27 Mart), s. 197 207.

ÖZBEK, Veli Özer, "Organize Suçlulukla Mücadelede Ön Alan Soruşturmaları", Dokuz Eylül Üniversitesi Hukuk Fakültesi Dergisi, sa. 4, y. 2002, s. 57 - 88.

ÖZGENÇ, İzzet, Suç Örgütleri, 13. Bası, Ankara 2020 (Suç Örgütleri).

ÖZGENÇ, İzzet, Türk Ceza Hukuku Genel Hükümler, 16. Bası, Ankara 2020 (Türk Ceza Hukuku Genel Hükümler).

ÖZGENÇ, İzzet / YURTLU, Fatih, “Suçtan Kaynaklanan Malvarlı̆̆ı Değerlerini Aklama Suçları Bakımından Teori ve Uygulamada Ortaya Çıkabilecek Sorunlara İlişkin Bir Değerlendirme". 5. Türk - Kore Ceza Hukuku Günleri Karşılaştırmalı Hukukta Ekonomik Suçlar Uluslararası Sempozyumu Tebliğler Kitabı, Editörler: İzzet ÖZGENÇ / Cumhur ŞAHİN / Faruk TURHAN, Ankara 2020, c. I, s. $447-471$.

RADTKE, Henning / STEINSIEK Mark, “Bekämpfung des internationalen Terrorismus durch Kriminalisierung von Vorbereitungshandlungen?

- Zum Entwurf eines Gesetzes zur Verfolgung der Vorbereitung von schweren Gewalttaten (Referentenentwurf des BMJ vom 21.4.2008)", ZIS 9/2008, s. 383 - 396.

RAHMDEL, Mansour, "Organized Crimes and Organized Criminal Groups In the Iranian Criminal Law", Dr. Silvia Tellenbach'a Armağan, Ankara 2018, s. 583 - 599.

SANCAR, Türkan Yalçın, Çok Failli Suçlar. Ankara 1998.

SIEBER, Ulrich, "Der Paradigmenwechsel vom Strafrecht zum Sicherheitsrecht in: Tiedemann/Sieber/Burchard/Brodowski (Hrsg.)", Die Ver- 
fassung moderner Strafrechtspflege, Erinnerung an Joachim Vogel, Baden-Baden 2016, 349 - 372.

SÖZÜER, Adem, Suça Teşebbüs, İstanbul 1994.

Terörle Mücadele Kanunu Tasarısı ve Adalet Komisyonu Raporu, TBMM, Dönem: 18, Yasama Y1l1 4, sa. 554.

Türk Ceza Kanunu Tasarısı ve Adalet Komisyonu Raporu (1/593), Dönem: 22, Yasama Y1l1: 2, T.B.M.M. (S. Say1s1: 664).

WEIßER, Bettina, "Der "Kampf gegen den Terrorismus" - Prävention durch Strafrecht?", JZ 2008, s. 388 - 395.

WEIßER, Bettina, "Uber den Umgang des Strafrechts mit terroristischen Bedrohungslagen", ZStW 121/2009, s. 131 - 161.

YENISEY, Feridun / PLAGEMANN Gottfried, Alman Ceza Kanunu Strafgesetzbuch (StGB), 2. Baskı, İstanbul 2005.

YURTLU, Fatih, İhmali Suçlar, Ankara Hacı Bayram Veli Üniversitesi Lisansüstü Eğitim Enstitüsü, Yayımlanmamış Doktora Tezi, Ekim 2020.

YURTLU, Fatih, Suç İşlemek Amacıyla Örgüt Kurma, Kurulmuş Örgütü Yönetme veya Bu Örgüte Üye Olma, Yayımlanmamış Yüksek Lisans Tezi, Gazi Üniversitesi Sosyal Bilimler Enstitüsü, Ankara 2013.

YURTLU, Fatih, "Suç Örgütünün Propagandasını Yapma Suçu ve Türkiye Açısından AIHHM Kararlarına Yansıması", Gazi Üniversitesi Hukuk Fakültesi Dergisi, C. xx, sa. 3, y. 2016 (Temmuz), s. 411 435.

ZWEIGLE, Thiemo Alexander, Gesetzgeber im Konflikt zwischen Rechtsstaatlichkeit und Terrorismusbekämpfung, Eine Untersuchung zu § 89a Abs. 2a StGB, Baden-Baden 2020.

Yararlanılan İnternet Kaynakları

Frankfurter Allgemeine (online), 14.4.2016, "Koalition verständigt sich auf Integrationsgesetz und Sicherheitspake", http://www.faz.net/aktuell/politik/inland/koalitionsgipfel-zufluechtlingen-anti-terror-kampf-14177429.html, siteye erişim tarihi: 12.01.2021. 
"Interview Bundesanwalt Rainer Griesbaum / Dschihad-Werbung ist strafbar", 24.02.2009, von Christian Rath, http://www.taz.de/!5167298/, siteye erişim tarihi: 12.01.2021.

Süddeutsche Zeitung (Online), "Allgemeine Aufrufe zum Dschihad nicht mehr strafbar", 17.05.2010, https://www.sueddeutsche.de/politik/bgh-allgemeine-aufrufezum-dschihad-nicht-mehr-strafbar-1.318482, siteye erişim tarihi: 12.01.2021.

Türk Dil Kurumu (Online) Güncel Türkçe Sözlük , https://sozluk.gov.tr/, siteye erişim tarihi: 07.12.2020.

Welt (online), 10.09.2014, “Offene Sympathie für Terror soll strafbar werden", von Martin "Outz, https://www.welt.de/politik/deutschland/article132063910/Offe ne-Sympathie-fuer-Terror-soll-strafbar-werden.html, siteye erişim tarihi: 12.01.2020.

Welt (online), 16.02.2018, "NRW bringt neues Sicherheitspaket gegen Terror auf den Weg", https://www.welt.de/regionales/nrw/article173664358/NRWbringt-neues-Sicherheitspaket-gegen-Terror-auf-den-Weg.html, siteye erişim tarihi: 12.01.2021.

“Werbung für Terrororganisationen: Muss Sympathie strafbar sein?", 30.09.2014, von Christian Rath, http://www.taz.de/!5032135/, siteye erişim tarihi: 12.01.2021.

YCGK, E. 1999/9-33, K. 1998/38, T. 16.3.1999, Kazancı İçtihat Bankası, http://www.kazanci.com/kho2/ibb/giris.htm, siteye erişim tarihi: 07.12.2020.

ZIMMERMANN, Frank, "NS-Propaganda im Internet, §86a StGB und deutsches Strafanwendungsrecht", https://www.hrrstrafrecht.de/hrr/archiv/15-11/index.php?sz=7, siteye erişim tarihi: 10.12.2020.

Yararlanılan BGH Kararları

BGH -3 StR 182/79 (S), Urt. v. 25.07.1979, https://research.wolterskluweronline.de/document/c6c8d84a-e74a-474f-83fd-19a39170a751, siteye erişim tarihi: 07.12.2020. 
BGH -3 StR 613/98, 26.02.1999 Urteil (LG Bochum), https://www.hrrstrafrecht.de/hrr/3/98/3-613-98.php3, siteye erişim tarihi: 10.12.2020.

BGH -3 StR 495/01 - 31. 07. 2002 (KG Berlin), https://www.hrrstrafrecht.de/hrr/3/01/3-495-01.php3, siteye erişim tarihi: 10.12.2020.

BGH -3 StR 602/14, 14.04.2005 (LG Berlin), https://www.hrrstrafrecht.de/hrr/3/14/3-602-14.php, siteye erişim tarihi: 10.12.2020.

BGH - AK 18/11, Beschluss vom 15. November 2011, https://www.hrrstrafrecht.de/hrr/2/11/ak-18-11.php, siteye erişim tarihi: 12.01.2021.

BGH - 3 StR 314/12, 20.09.2012, https://www.hrr-strafrecht.de/hrr/3/12/3314-12.php, siteye erişim tarihi: 13.01.2021.

BGH -3 StR 109/13, 28.07.2013 Urteil (LG Berlin), https://www.hrrstrafrecht.de/hrr/3/13/3-109-13.php, siteye erişim tarihi: 12.01.2021.

BGH -3 StR 265/13, Beschluss vom 6. Mai 2014 (OLG Hamburg), https://www.hrr-strafrecht.de/hrr/3/13/3-265-13.php, siteye erişim tarihi: 12.01.2021.

BGH -3 StR 407/13, Beschluss vom 6. Mai 2014 (KG Berlin), https://www.hrr-strafrecht.de/hrr/3/13/3-407-13.php, siteye erişim tarihi: 12.01.2021.

BGH -3 StR 33/15, 09.07.2015 Urteil (LG Bochum), https://www.hrrstrafrecht.de/hrr/3/15/3-33-15.php, siteye erişim tarihi: 06.12.2020.

BGH -3 StR 218/15, 27.10.2015 Urteil (LG München I), https://www.hrrstrafrecht.de/hrr/3/15/3-218-15.php, siteye erişim tarihi: 10.01.2021.

BGH -AK 52/16, Beschluss vom 6. 10. 2016, https://lexetius.com/2016,3316, siteye erişim tarihi: 13.01.2021.

BGH -AK 3/18, Beschluss v. 8. Februar 2018, http://juris.bundesgerichtshof.de/cgibin/rechtsprechung/document.py?Gericht=bgh\&Art=en\&az=A K\%203/18\&nr=81294, siteye erişim tarihi: 12.01.2021. 
2208 | Dr. Öğr. Üyesi Fatih YURTLU

BGH - StB 13/19, Beschluss v. 13.06.2019 OLG (Celle), HRRS 2019 nr. 819, kn. 37. https://www.hrr-strafrecht.de/hrr/2/19/stb-13-19.php , siteye erişim tarihi: 14.01.2021.

BGH -3 StR 88/14, HRRS 2014 Nr. 1113, https://www.hrrstrafrecht.de/hrr/archiv/15-11/index.php?sz=7 , siteye erişim tarihi: 10.12.2020. 